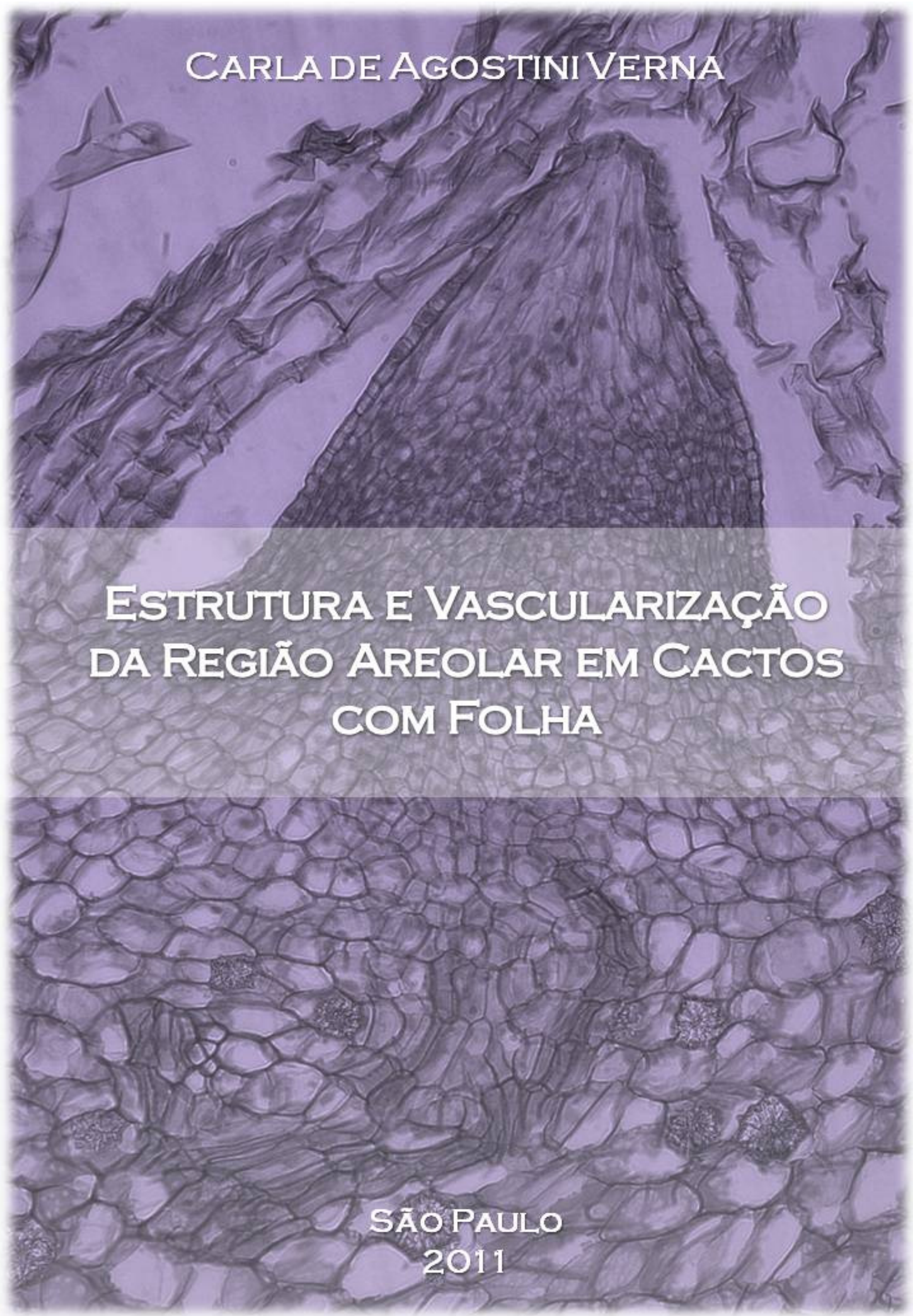


Carla de Agostini Verna

Estrutura e vascularização da região areolar em cactos com folha

Structure and vascularization of areolar region in leaf cacti

São Paulo 

Carla de Agostini Verna

\section{Estrutura e vascularização da região areolar em cactos com folha}

\section{Structure and vascularization of areolar region in leaf cacti}

Dissertação apresentada ao Instituto de Biociências da Universidade de São Paulo, para a obtenção de Título de Mestre em Ciências, na Área de Botânica (Anatomia Vegetal).

Orientadora: Profa. Dra. Gladys Flávia Melo-de-Pinna.

São Paulo

2011 
Verna, Carla

Estrutura e vascularização da região areolar em cactos com folha.

70 páginas

Dissertação (Mestrado) - Instituto de Biociências da Universidade de São Paulo. Departamento de Botânica.

1. Cactaceae; 2. Opuntia; 3. Pereskia; 4. Maihuenia; 5. Aréola; 6. Axila foliar; 7.

Portulacineae.

\section{Comissão Julgadora:}


Aos meus maravilhosos pais, à minha inesquecível irmã, à minha adorável avó, ao meu querido cunhado e ao meu amado noivo. 

A liberação do poder do átomo mudou tudo exceto nosso modo de pensar. A solução para esse problema reside no coração da humanidade. Se eu tivesse idéia, teria me tornado um relojoeiro.

Albert Einstein, Watchmen. 


\section{Agradecimentos}

À minha querida orientadora, Profa. Gladys Flávia Melo-de-Pinna, por ser essa pessoa maravilhosa, uma pesquisadora que não se contenta com pouco, uma professora talentosa. Obrigada por tudo que você me ensinou nesses seis anos em que trabalhamos juntas, por me mostrar que é possível ter sucesso mantendo o caráter e a dignidade, sendo gentil e amiga de todos. Pode ter certeza que vou levar isso comigo o resto da vida.

Aos meus colegas de orientadora: Aline Nunes, Vanessa Godofredo, Natália Antonucci, Maria Cristina Zampieri, Thais Muntoreanu, Roberta Magna, Diego Mañas, Deusa Deise, pelas discussões e revisões de textos, além dos momentos de descontração que passamos juntos. Em especial, gostaria de agradecer à Renata Lemos, por toda ajuda que me deu desde que iniciei no laboratório, sempre disposta; ao Rafael Cruz e Mario Albino, com quem viajei para coleta, pelos momentos inesquecíveis que passamos juntos, e por todo auxílio que vocês me deram durante o mestrado e principalmente no final dele; ao incrível José Hernandes, por todos os momentos de desespero que vivemos juntos, mas também pelas risadas e confissões que compartilhamos.

À Emília Arruda, que foi quem me guiou no Laboratório de Anatomia quando comecei, confiando o material do seu mestrado em minhas mãos desastradas. Obrigada pelo companheirismo, pelos conselhos, pelas conversas que tivemos. Você se tornou um modelo para mim, e eu espero que sua vida seja cheia de vitórias, porque você merece cada uma delas.

Aos professores do Laboratório de Anatomia Vegetal: Profa. Berta Lange de Morretes, Profa. Nanuza Luiza de Menezes, Profa. Maria Emília Estelita, Profa. Verônica Angyalossy, Prof. Gregório Ceccantini, Profa. Gladys Flávia Melo-de-Pinna e Prof. Diego Demarco, por todo conhecimento que passam aos alunos de graduação de pósgraduação, além de transpirarem a paixão que têm pela pesquisa que fazem, inspirando alunos de todo Instituto.

Às técnicas do Laboratório de Anatomia Vegetal, Gisele Costa e Tássia Santos, por se desdobrarem em mil pra atender todo mundo, além de dividir a vasta experiência que possuem conosco, tornando nosso trabalho no laboratório mais produtivo. Obrigada pela paciência que tiveram comigo, quando meu lado desastrado acabava por quebrar alguma coisa (e olha que isso não aconteceu poucas vezes!). Ao Irwandro Pires, pelo processamento do material para microscopia eletrônica. Também gostaria de agradecer à Paula Jardim, Viviane Jono e Suzi da Silva pelos momentos de descontração compartilhados na hora de almoço. 
Aos meus colegas do laboratório: Gustavo Burin, Giuliano Lecosselli, Cairo Faleiros, Guilherme Freire, André Lima, Cristiane Gonçalves, Luiz Horta, Paula Elbl, Flávia Nascimento. Sempre animados, tornando o dia a dia no laboratório mais agradável, sempre prontos para socorrer qualquer emergência.

Ao Prof. Roberto Kiesling, por me receber na Argentina para coletar material, juntamente com a Profa. Irma Del Vitto, Profa. Iris Peralta, Profa. Cecília, Sofia Albesiano e Mônica, da IADIZA, por me receberem tão bem no instituto e serem tão prestativos. À Profa. Eny Floh e ao Prof. José Rubens Pirani, por cederem seus respectivos microscópios e equipamento de registro fotográfico quando o nosso ficou indisponível.

Ao Instituto de Biociências da Universidade de São Paulo, por toda a infra-estrutura e base científica através de professores e material didático, que foram não só necessários para a realização desse trabalho, mas indispensáveis na minha formação acadêmica desde a graduação.

À Fundação de Amparo à Pesquisa do Estado de São Paulo (FAPESP), pela bolsa de Mestrado Processo No. 2009/03756-3, e também ao Conselho Nacional de Desenvolvimento Científico e Tecnológico (CNPq), pelo financiamento de material e equipamentos do Laboratório de Anatomia e utilizados para a realização deste trabalho.

Aos meus amigos que conheci em diversos momentos da minha vida e que sempre estiveram dispostos a me ajudar. Aos meus amigos da graduação, Mariana Winandy (meu "radinho" pessoal durante as aulas!), André Pimentel, Janaína Meyer, Ludvine, Mariana, Maria Koga, Dayane, Márcio, Maíra Nagai, Bruno Queliconi. À Sabrina Rodrigues, com quem estudei inglês e nos tornamos amigas de estudo e confusões juntas. Aos meus queridos amigos e companheiros RPGistícos, Bárbara (Babi) Tomotani, Rodrigo (Hammer) Salvador, Vivi Café, Daniel Simons, Artur (O Fighter), Nori (O Brigão), Davi (O Estranho), Daniel (Musgo) Caetano, João (Johan) Tomotani, Rodrigo (Sumô) Nakagawa, Karen Mayumi. Obrigada por proporcionar momentos de distração, por todos os conselhos que vocês me deram, por serem meus amigos a ponto de me dizer quando eu estava errada, por me confortar quando eu chorei (e eu choro pra caramba!) e de me apoiar, sempre.

Aos meus pais, Carlos Alberto Verna e Elizete de Agostini Verna, que sempre me apoiaram e incentivaram, ouvindo tudo o que eu tinha a dizer quando eu assistia ao "O Mundo de Beckman" com meus oito anos, já fascinada com a Ciência, ou contando o que eu aprendi na escola ou na faculdade, sempre interessados. Só cheguei onde estou agora por causa de vocês, de tudo que vocês fizeram por mim. Eu nunca vou me esquecer disso, nem de todo o amor, carinho e dedicação com os quais vocês nos criaram. 
Á minha amada irmã, Juliana de Agostini Verna, sempre junto comigo, brincando (e às vezes brigando também), por todas as risadas que demos juntas, e por todas as risadas que ainda vamos dar. Ao mais novo membro da família Verna, Roger Xavier, pelos momentos de diversão que passamos juntos. Que vocês dois sejam muitos felizes, e que cuidem bem do meu(minha) sobrinho(a)!!!

Aos meus avós, Jacyra Thomé de Agostini, e, in memorian, José Verna, Maria Cândida Pomeli Verna e Júlio de Agostini, que sempre foram carinhoso e atenciosos comigo. Sei que vocês se orgulham de mim, e prometo que vou continuar fazendo o meu melhor, sempre.

Ao meu maravilhoso noivo, Aaron Samuel Evans, por todo o carinho e compreensão que tem por mim. Weird how our paths crossed, but there isn't a day I don't thank God for this. Sempre me apoiando, até durante o meu desespero na reta final do meu trabalho, sempre com um sorriso dizendo "it will be ok, you'ill see".

Enfim, agradeço a todos vocês, por tudo. Se eu sou hoje uma pessoa melhor, foi porque vocês mudaram algo na minha vida, e eu nunca vou me esquecer disso.

\section{Obrigada!}




\section{Índice}

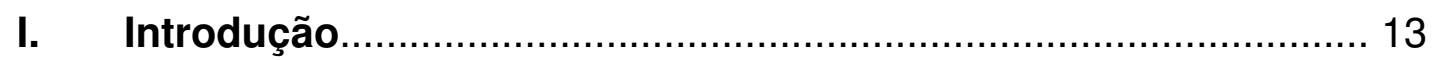

Caracterização da família Cactaceae........................................ 13

Aréola: breve histórico e caracterização..................................... 15

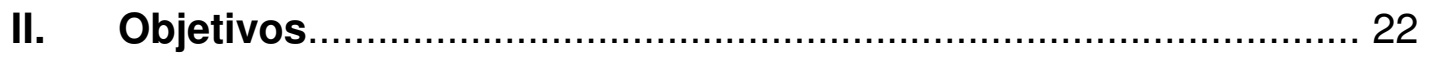

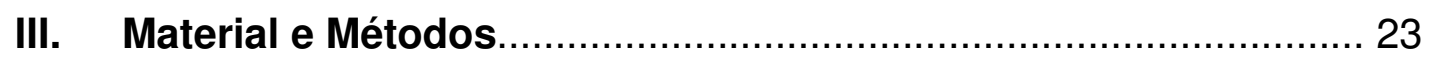

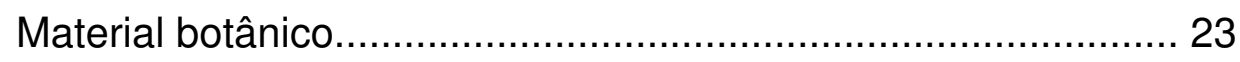

Análise em microscopia óptica................................................. 24

Análise em microscopia eletrônica de varredura (MEV)............. 25

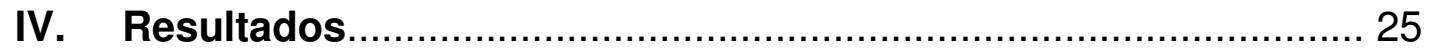

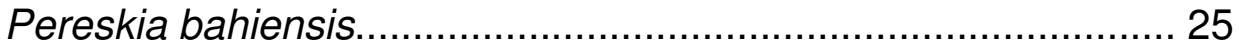

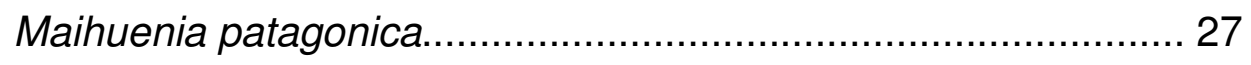

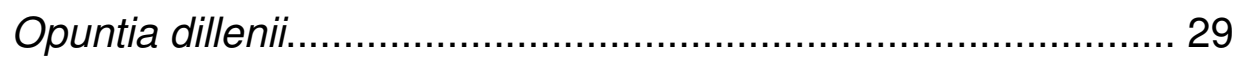

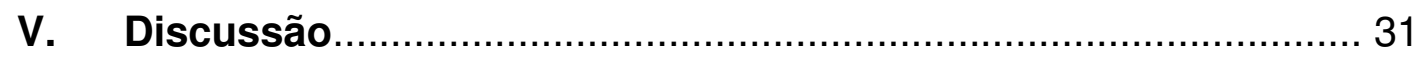

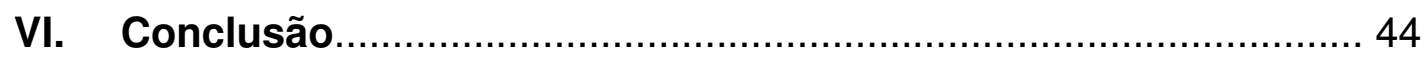

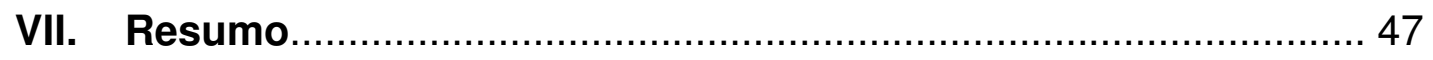

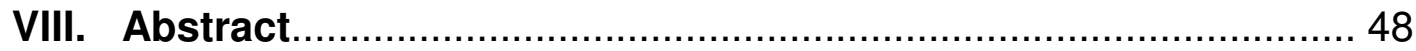

IX. Referências Bibliográficas...................................................... 49

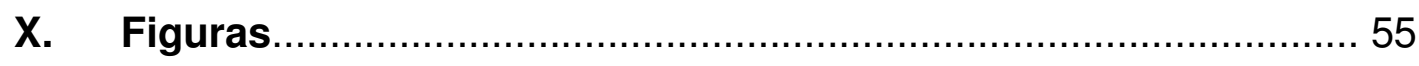





\section{Introdução}

\section{Caracterização da família Cactaceae}

A família Cactaceae está inserida na ordem Caryophyllales, grupo atualmente reconhecido contendo 34 famílias, 811 gêneros e 11510 espécies (Stevens 2001). Desse total, 14 famílias possuem espécies nativas do Brasil, tornando a ordem relativamente bem representada no país (Souza \& Lorenzi 2005). Além de Cactaceae, outras famílias importantes compõem o grupo, como Nyctaginaceae, Amaranthaceae, Portulacaceae e Aizoaceae (Stevens 2001; Judd et al. 2002; Souza \& Lorenzi 2005).

Dos 100 gêneros e 1500 espécies que compõem Cactaceae, 40 gêneros e 200 espécies ocorrem no Brasil (Souza \& Lorenzi 2005). A família apresenta distribuição neotropical (Stevens 2001; Judd et al. 2002; Souza \& Lorenzi 2005), com apenas o gênero Rhipsalis ocorrendo também na África, Austrália e Índia (Judd et al. 2002).

Como característica da família, é possível listar a presença de suculência, folhas geralmente reduzidas ou ausentes, frequentemente modificadas em espinhos, e ramos curtos (aréolas) produzindo espinhos ou conjuntos de espinhos (Judd et al. 2002; Souza \& Lorenzi 2005).

Cactaceae é tradicionalmente dividida em Pereskioideae, Maihuenioideae, Opuntioideae e Cactoideae (Anderson 2001), mas trabalhos atuais com dados moleculares questionam a monofilia de Pereskioideae (Edwards et al. 2005, Edwards \& Donoghue 2006). Segundo Edwards \& Donoghue (2006), 
Pereskioideae está dividida em dois grupos distintos (Fig. 1): Rhodocactus, ou clado A, com espécies de Pereskia encontradas principalmente no Caribe, México e Brasil (denominadas "Northern Pereskia clade"); e as demais espécies de Pereskia, clado B, encontradas na América do Sul e Andes, formando o grupo caulocacti com Opuntioideae + [Maihuenioideae + Cactoideae]. Os representantes de Pereskioideae são caracterizados pela presença de estados de caracteres plesiomórficos, como caules não suculentos e folhas bem desenvolvidas e persistentes (Anderson 2001; Judd et al. 2002; Wallace \& Gibson 2002).

Maihuenioideae, que é composta por apenas um gênero com duas espécies, Maihuenia patagonica e Maihuenia poeppigii (Anderson 2001; Wallace \& Gibson 2002), ocorre apenas próxima à Cordilheira dos Andes, na Argentina e Chile, e possuem folhas pequenas e persistentes (Anderson 2001; Stevens 2001).

Opuntioideae apresenta gloquídeos (espinhos modificados) nas aréolas, além de folhas presentes, porém efêmeras, que podem ser persistentes em Pereskiopsis (Anderson 2001; Stevens 2001; Judd et al. 2002; Wallace \& Gibson 2002). Por fim, Cactoideae é o grupo que apresenta as características mais derivadas da família, entre elas a extrema redução ou completa perda das folhas (Anderson 2001; Stevens 2001; Judd et al. 2002; Wallace \& Gibson 2002). 


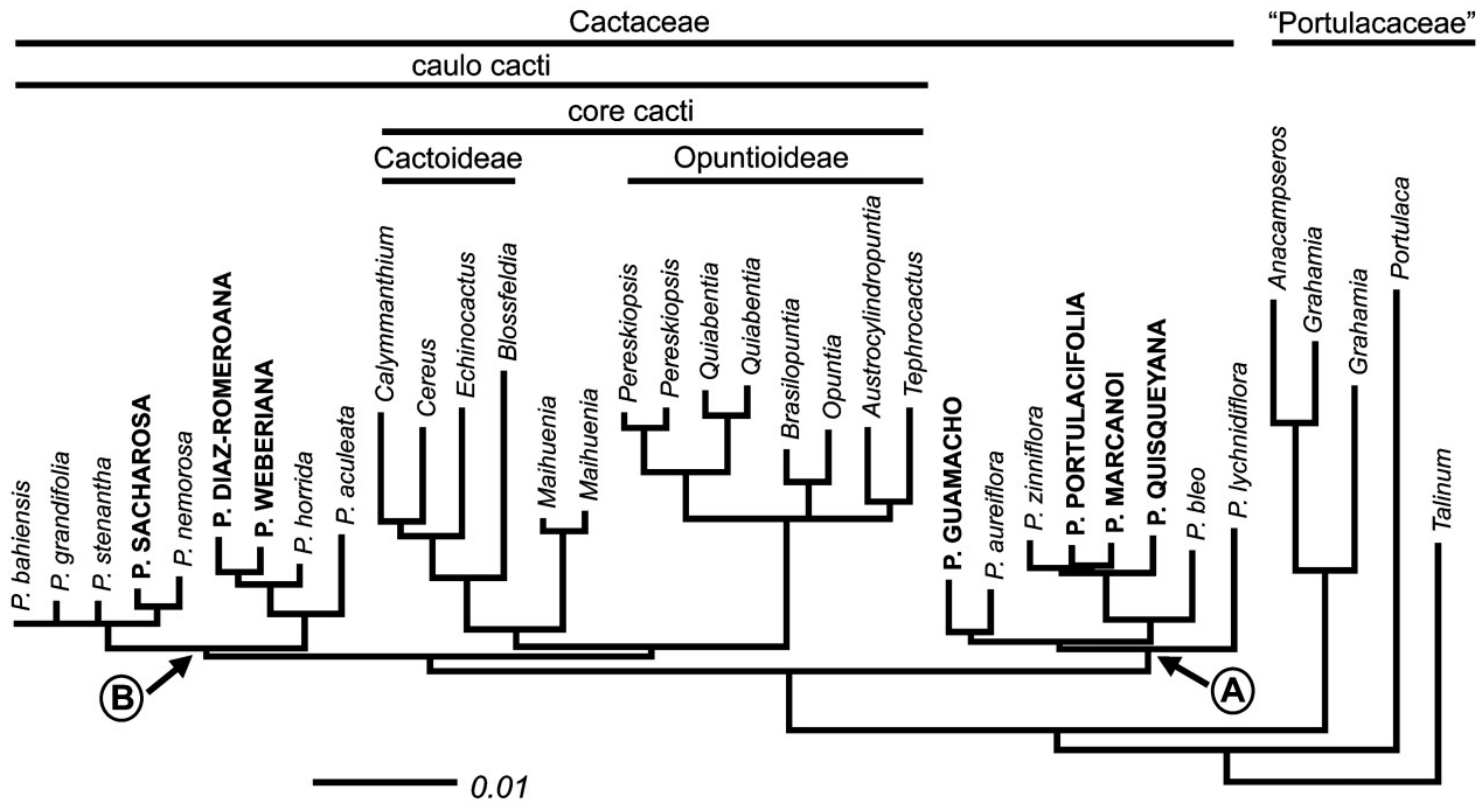

Figura 1: Filogenia basal de Cactaceae, mostrando em especial dois grupos distintos formados por Pereskia. Retirado de Edwards \& Donoghue (2006).

\section{Aréola: breve histórico e caracterização}

Uma das características mais marcantes na família, como já citado anteriormente, é a presença de aréolas na região da axila foliar, nas quais são encontrados tricomas, espinhos e primórdios foliares, além de uma região que se mantêm meristemática, definida como meristema areolar (Boke 1944,1954, 1980; Gibson \& Nobel 1986). Essas características permitem definir a aréola como sendo um pequeno ramo lateral modificado (Salgado \& Mauseth 2002). Em representantes de Opuntioideae, o meristema areolar produz também gloquídeos, os quais são pequenos espinhos não esclerificados em sua região basal e, portanto, são facilmente destacáveis da aréola, além de apresentar as células mais externas em forma de farpa (Boke 1944, Gibson \& Nobel, 1986).

A estrutura e o desenvolvimento da aréola em Cactaceae foram temas de vários estudos (Tabela 1). O primeiro trabalho morfológico dessa estrutura foi 
feito por DeCandolle (apud Boke 1944), e Norman Boke se interessou pelas aréolas após seu trabalho observando a zonação em ápices caulinares de Opuntia cylindrica e Trichocereus spachianus (Boke 1941), que se dá pela presença de 4 zonas presentes no meristema apical (Fig. 2):

a. Zona 1: túnica, camada mais externa do meristema, geralmente formada por apenas uma camada de células, dando origem à epiderme;

b. Zona 2: grupo de células menores, visivelmente meristemáticas, de citoplasma denso, as quais formam a zona 3 ou 4;

c. Zona 3: células nos flancos da zona 2, estão mais alongadas e vacuoladas e dão origem ao sistema vascular, região cortical (incluindo feixes corticais) e órgãos foliares;

d. Zona 4: células internas à zona 2, alongadas e vacuoladas, que dão origem à região medular e aos feixes medulares.

Ainda nesse trabalho, o autor relatou que a formação de tecido vascular ocorre apenas nos primórdios foliares originados diretamente do meristema apical caulinar, e não nas estruturas produzidas pela aréola.

Em 1944, Norman Boke iniciou os estudos detalhados de aréola ao descrevê-las em Opuntia cylindrica, definindo essa estrutura como uma gema axilar e comparando o meristema areolar com o meristema apical, os quais, segundo o autor, possuem as mesmas zonas, porém organizadas de forma diferente. N. Boke observou também formação de espinhos, gloquídeos e tricomas, sendo a diferenciação do espinho acrópeta, com vascularização apenas até a base. Além disso, observou ainda estruturas intermediárias entre folhas e espinhos e entre espinhos e gloquídeos, afirmando que tanto espinhos 
quanto gloquídeos são folhas modificadas. Por fim, o autor observou a formação de um súber (“cork") na aréola, encontrado na base dos espinhos e produzido pelo felogênio hipodérmico. Os tricomas são sempre produzidos pelas células protodérmicas e podem produzir um pseudotecido em sua base, que torna difícil a localização da epiderme.

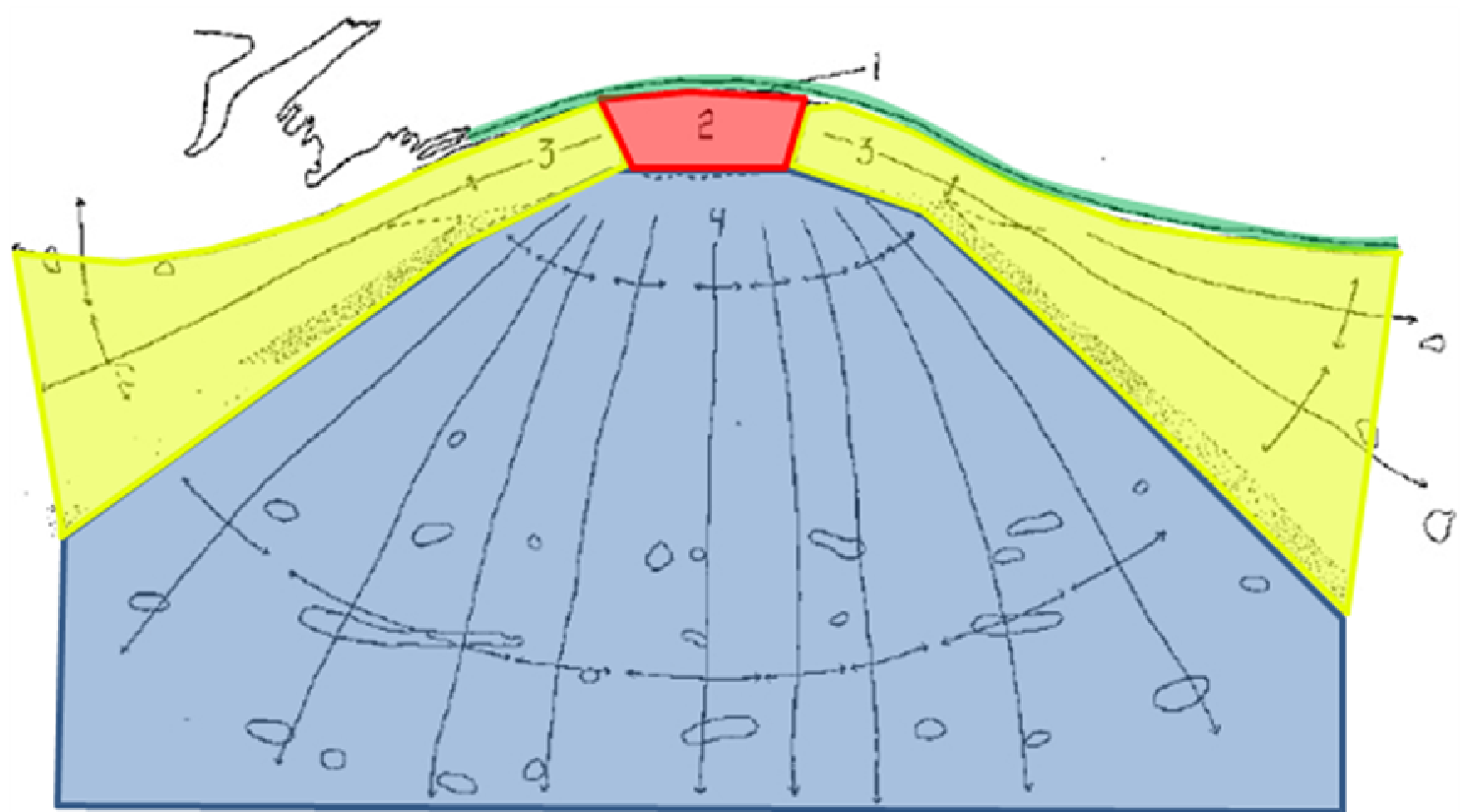

Figura 2: Meristema apical em Trichocereus spachianus. Zona 1 representada pela cor verde, zona 2 representada pela cor vermelha, zonas 3 representadas pela cor amarela e a zona 4 representada pela cor azul. Modificado de Boke (1941).

Continuando seus trabalhos, na busca por informações sobre a origem foliar dos espinhos em Cactaceae, Boke (1951) investigou outros grupos, como Echinocereus reichenbachii (Cactoideae), afirmando que o meristema areolar é comparável ao de uma gema axilar e que não foi registrado qualquer indício de vascularização nos espinhos. Em geral, a organização areolar é semelhante à de Opuntia cylindrica, porém sem a presença de gloquídeos ou estruturas intermediárias entre folha e espinho. 
Tabela 1. Lista dos principais trabalhos realizados com representantes de Cactaceae, contendo os aspectos mais relevantes.

\begin{tabular}{|c|c|c|}
\hline Espécie & Aspectos mais relevantes para o presente estudo & Referência \\
\hline $\begin{array}{lr}\text { Opuntia cylindrica } & \text { (Lamarck) } \\
\text { DeCandolle e } & \text { Trichocereus } \\
\text { spachianus } & \text { (Lemaire) } \\
\text { Riccobono } & \end{array}$ & $\begin{array}{l}\text { Zonação no ápice caulinar de } O \text {. cylindrica com cordões vasculares } \\
\text { relacionados a primórdios foliares. }\end{array}$ & \\
\hline $\begin{array}{l}\text { Opuntia cylindrical (Lamarck) } \\
\text { DeCandolle }\end{array}$ & $\begin{array}{l}\text { Anatomia da aréola, formação dos espinhos, tricomas, gloquídeos e } \\
\text { desenvolvimento das folhas. Vascularização até a base do espinho. }\end{array}$ & Boke, 1944 \\
\hline $\begin{array}{l}\text { Echinocereus reichenbachii } \\
\text { (Terscheck) Haage jr. }\end{array}$ & Formação de espinhos e tricomas, ausência de vascularização nos espinhos. & Boke, 1951 \\
\hline $\begin{array}{l}\text { Coryphantha vivipara (Nuttall) } \\
\text { Britton \& Rose }\end{array}$ & Anatomia, formação de espinhos, tricomas. & Boke, 1952 \\
\hline Mammillaria heyderi Muehl & Anatomia, formação e desenvolvimento da base foliar. & Boke, 1953 \\
\hline $\begin{array}{l}\text { Pereskia aculetata Miller, } P . \\
\text { grandifolia Haworth, } \\
\text { cubensis Britton \& Rose }\end{array}$ & $\begin{array}{l}\text { Anatomia da aréola, formação de espinhos, folhas e tricomas. Presença de } \\
\text { meristema na base do espinho em } P \text {. cubensis. }\end{array}$ & Boke, 1954 \\
\hline Rhipsalis cassytha Gaertner & $\begin{array}{l}\text { Formação de primórdio foliar, espinho e tricomas. Vascularização somente na } \\
\text { folha. }\end{array}$ & Boke, 1955 \\
\hline $\begin{array}{l}\text { Bartschella schumanni } \\
\text { Hildmann }\end{array}$ & $\begin{array}{l}\text { Formas intermediárias entre base foliar expandida e espinhos, com } \\
\text { vascularização. }\end{array}$ & Boke, 1956 \\
\hline $\begin{array}{l}\text { Homalocephala texensis Britton } \\
\text { \& Rose, Echinocactus grusonii } \\
\text { Hildmann e Echinocactus } \\
\text { horizonthalonius Lemaire }\end{array}$ & Anatomia da aréola; traço de aréola até a região basal da folha. & Boke, 1957 \\
\hline $\begin{array}{l}\text { Mammilaria lasiacantha } \\
\text { Engelmann }\end{array}$ & Anatomia, formação de espinhos e tubérculos. & Boke, 1958 \\
\hline $\begin{array}{l}\text { Opuntia basilalis Engelm. \& } \\
\text { Bigel. }\end{array}$ & $\begin{array}{l}\text { Desenvolvimento, vascularização na base de gloquídeos. Inicialmente } \\
\text { gloquídeos e folhas não são distinguíveis entre si. }\end{array}$ & Freeman, 1970 \\
\hline $\begin{array}{l}\text { Opuntia badtiana (Coult.) K. } \\
\text { Brandegee, O. santamaria (E. M. } \\
\text { Baxter) Wiggins e O. kunzei } \\
\text { Rose }\end{array}$ & Anatomia da aréola, vascularização ausente em espinhos e gloquídeos. & Hamilton, 1970 \\
\hline $\begin{array}{lr}\text { Revisão de } & \text { aspectos } \\
\text { morfológicos } & \text { do } \\
\text { desenvolvimento de } & \text { Cactaceae. }\end{array}$ & $\begin{array}{l}\text { Vascularização até a base dos espinhos e de formas intermediárias entre } \\
\text { espinhos-folhas. }\end{array}$ & Boke, 1980 \\
\hline $\begin{array}{l}\text { Revisão de vários aspectos de } \\
\text { Cactaceae. }\end{array}$ & Vascularização até a base dos espinhos, formação dos produtos da aréola. & $\begin{array}{l}\text { Gibson \& Nobel, } \\
1986\end{array}$ \\
\hline 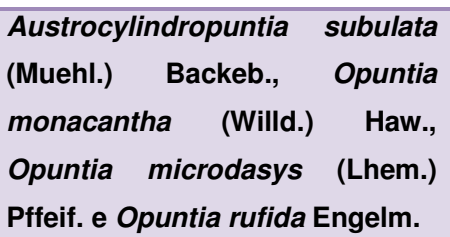 & $\begin{array}{l}\text { Anatomia da aréola, formas intermediárias entre espinho e folha em } O \text {. } \\
\text { microdasys. }\end{array}$ & Arruda, 2010 \\
\hline
\end{tabular}

Vários outros trabalhos foram realizados por Norman Boke sobre anatomia das estruturas vegetativas e a formação de folhas, espinhos e tricomas em 
Coryphantha vivipara (Boke 1952) e Mammillaria heyderi (Boke 1953), descrevendo a formação de "tubercles" e costelas a partir da expansão e crescimento da base foliar, em conjunto com parte da região cortical. Em $C$. vivipara, o autor observou ainda dois cordões procambiais próximos ao meristema areolar e primórdios de espinhos que se diferenciam e se ligam ao traço de folha.

Em 1954, N. Boke analisou três espécies de Pereskia ( $P$. aculetata, $P$. grandifolia e $P$. cubensis), introduzindo a terminologia de estruturas produzidas abaxial ou adaxialmente a partir do meristema da aréola, sendo que o primeiro é referente a estruturas localizadas entre a folha e o meristema areolar e o segundo se refere às estruturas presentes entre o meristema areolar e o segmento caulinar. Nesse trabalho, o autor relatou que em $P$.grandifolia e $P$. cubensis zonação presente no meristema areolar idêntica ao meristema apical, assim como ocorre nas espécies estudadas anteriormente (Boke 1941, 1951, 1952 e 1953). Em P. grandifolia, com a abscisão foliar, a aréola passa a produzir um ramo com folhas em meio aos espinhos ("spur shoot”). O autor observou também que os tricomas, nessa espécie, podiam apresentar divisões anticlinais em sua base, indicando uma situação multisseriada. No entanto, em $P$. aculeata foram observados apêndices multisseriados, que se assemelham aos espinhos por apresentarem um meristema intercalar basal e uma região apical já diferenciada que, segundo o autor, são definidos como emergências ou tricomas modificados. O estudo relata ainda a presença de um meristema axilar no espinho em $P$. cubensis, sendo esse o único registro de meristema axilar em espinhos de Cactaceae, reforçando a hipótese de essas estruturas terem uma origem foliar. 
Voltando para outros representantes de Cactoideae, Boke (1955) analisou a região areolar de Rhipsalis cassytha, relatando a diferente atividade das aréolas terminais (localizadas nas extremidades de ramos mais velhos e que dão origem à maior parte do crescimento vegetativo) em relação às laterais (responsáveis pelas ramificações de um eixo caulinar), principalmente quanto ao número e grau de desenvolvimento das estruturas produzias.

Outros grupos de Cactaceae foram estudados por Boke (1956, 1957, 1958, 1960, 1961), onde o mesmo padrão de desenvolvimento e organização da região areolar foi observado, variando em geral o número de espinhos produzidos e sua disposição na região.

Trabalhos posteriores corroboram as observações feitas por Norman Boke. Hamilton (1970) e Freeman (1970) publicaram estudos morfológicos e anatômicos em espécies do gênero Opuntia. Hamilton (loc. cit.) analisou comparativamente Opuntia badtiana, O. santamaria e O. kunzei, relatando a ausência de vascularização nos espinhos e gloquídeos. Já Freeman (loc. cit), embora não mencione a ocorrência de espinhos em $O$. basilaris, descreveu que nesta espécie folhas e gloquídeos são indistinguíveis um do outro no início do desenvolvimento e que, apesar de não haver sistema vascular no interior dos gloquídeos, é possível ver cordões procambiais próximos à base que se unem ao traço de folha. $O$ autor ainda cita que o meristema areolar de $O$. basilares é anatomicamente similar ao meristema apical.

Com tantos trabalhos já realizados sobre o tema, uma revisão dos aspectos morfológicos do desenvolvimento de Cactaceae foi realizada por Boke (1980). Neste artigo, o autor descreveu os principais trabalhos sobre estrutura da aréola, citando situações morfológicas intermediárias entre 
espinhos e folhas, destacando que, mesmo nesses casos, o sistema vascular está presente apenas na base, conforme descrito para os espinhos e gloquídeos.

Estudos sobre o desenvolvimento de tricomas em Cactaceae foram realizados por Gibson \& Nobel (1986), que os descrevem como estruturas unisseriadas que se desenvolvem a partir de uma única célula protodérmica. Esta célula sofre divisão periclinal e forma uma célula basal, que por sua vez dá origem ao tricoma através de divisões sucessivas, gerando uma cadeia de células muito alongadas. Ainda nesse trabalho, os autores afirmam que a não diferenciação do sistema vascular nos espinhos ocorre devido à forte ação da região meristemática na base do espinho e à rápida esclerificação das células do ápice, impossibilitando a transmissão do sinal de diferenciação.

Recentemente, Mauseth \& Landrum (1997) desenvolveram um trabalho com diversas espécies de Pereskia, buscando definir caracteres morfoanatômicos que corroborem a posição basal do gênero dentro da família Cactaceae. No entanto, os resultados apresentados quanto às estruturas presentes nas aréolas, não revelaram novos dados para o entendimento desse caráter no grupo.

O único estudo envolvendo anatomia de Maihuenia foi feito por Mauseth (1999), onde o autor descreveu as adaptações do gênero ao ambiente árido, porém não há um estudo detalhado da região areolar.

Recentemente, um estudo anatômico da região areolar de espécies de Opuntioideae foi realizado por Arruda (2010). A autora relata a presença de células de mucilagem na base dos gloquídeos e de formas intermediárias entre folhas e espinhos em Opuntia microdasys, como dados inéditos para o grupo e 
que podem, segundo a autora, contribuir para o entendimento da evolução dessas estruturas em Cactaceae.

Estudos iniciais feitos com Opuntia dillenii, resultado do projeto de iniciação científica desenvolvido por Carla Verna (FAPESP 2007/00246-9), mostram que o meristema areolar produz espinhos, gloquídeos e tricomas, sendo possível observar cordões de procâmbio apenas na base do espinho em diferentes estágios de diferenciação.

A necessidade de continuar com os estudos da região areolar em grupos ainda pouco estudados de Cactaceae, que possam trazer novas evidências sobre a evolução dessa estrutura no grupo impulsionou a realização deste estudo, o qual apresenta resultados sobre a região areolar de três espécies de cactos com folhas: Pereskia bahiensis Gürke (Pereskioideae), Opuntia dillenii (Ker Gawl.) Haw. (Opuntioideae) e Maihuenia patagonica (Phil.) Britton \& Rose

(Maihuenioideae). Os resultados são discutidos comparativamente com a literatura disponível, focando nas estruturas presentes na região areolar e suas características anatômicas que possam indicar uma provável origem foliar.

\section{Objetivos}

O objetivo geral deste trabalho foi realizar um estudo comparativo da região areolar em representantes folhosos de Cactaceae, buscando:

a. Descrever os produtos axilares (espinhos, gloquídeos, primórdios foliares e tricomas) a partir do meristema da aréola; 
b. Analisar aspectos anatômicos como vascularização da aréola e possíveis ramificações (traço foliar e traço de espinhos), presença de uma região meristemática basal, esclerificação da região apical e outras características que possam ser discutidas com base na proposta da origem foliar dessas estruturas.

\section{Material e Métodos}

\section{Material botânico}

Os exemplares de Pereskia bahiensis Gürke (Pereskioideae), Maihuenia patagonica (Phil.) Britton \& Rose (Maihuenioideae), que apresentam folhas durante as fases juvenil e adulta e Opuntia dillenii (Ker Gawl.) Haw. (Opuntioideae) que apresenta folhas apenas na fase juvenil foram obtidos por meio de coleta em campo e de casa de vegetação. Pereskia bahiensis possui hábito arbóreo e foi coletada em Mucugê, Vitória da Conquista e Chapada Diamantina, no estado da Bahia (Figs. 3-4). Opuntia dillenii, por sua vez, tem hábito arbustivo e foi coletada em Recife, Pernambuco (Figs. 5-6). No caso da Maihuenia patagonica, que forma arbustos cespitosos, os exemplares foram coletados na província de Mendoza, Diretório de Tupungato - Argentina, próximo ao Rio de Tuna, com o auxílio do Professor Dr. Roberto Kiesling, do Instituto Argentino de Investigaciones de las Zonas Áridas - IADIZA (Figs. 7-9), enquanto outra parte foi coletada da coleção particular do mesmo. Os materiais coletados foram fixados em FAA 70 (formaldeído, ácido acético e etanol 70\%, 1:1:18 V/V, Johansen 1940) e armazenados em etanol $70 \%$. 


\section{Análise em microscopia óptica}

Para o estudo da descrição das estruturas presentes, como tricomas e espinhos, foram retiradas amostras da região areolar nas porções apical, mediana e basal do segmento caulinar. O material já fixado em FAA 70 (formaldeído, ácido acético e etanol 50\%, 1:1:18 V/V, Johansen 1940) foi deixado novamente no fixador por uma semana. Após o processo de fixação, o material foi submetido à desidratação com etanol/butanol $70-100 \%$, cujas trocas foram realizadas a cada duas horas, sendo a sequência de desidratação etanol/butanol $70 \%, 85 \%, 95 \%$ e $100 \%$, para só então ser colocado em butanol PA por 12 horas. Após esse processo, o material foi submetido à técnica de infiltração e inclusão em parafina, segundo metodologia descrita por Ruzin (1999), consistindo em aumento gradual da concentração de butanol/parafina a cada três horas, sendo a inicial butanol/parafina 3:1, seguindo para $1: 1$, depois para 1:3, finalizando com o material em parafina pura por quatro horas em estufa a $60^{\circ} \mathrm{C}$. Os cortes foram realizados em micrótomo rotativo com navalha de aço, com espessura de até $12 \mu \mathrm{m}$. A coloração foi feita com uso de azul de astra $1 \%$ em etanol $50 \%$ por uma hora, seguida de safranina $1 \%$ em etanol $50 \%$ por meia hora (Kraus \& Arduin 1997, modificado). As lâminas permanentes foram confeccionadas com uso do Bálsamo do Canadá.

Para análise das estruturas foi utilizado o microscópio óptico Zeiss ICS Standard 25 e Leica DM 400B. O registro fotográfico dos principais caracteres encontrados foi realizado com auxílio de câmara digital acoplada ao fotomicroscópio Leica DFC425. 


\section{Análise em microscopia eletrônica de varredura (MEV)}

Durante esta análise foram observados aspectos morfológicos da região areolar, procurando caracteres que pudessem ser complementares à anatomia da aréola.

Para isso, foram analisadas aréolas em vista frontal (disposição geral de espinhos; tricomas e folhas). O material foi desidratado em série etanólica (70100\% EtOH) e submetido ao ponto crítico com gás carbônico para secagem (CPD 030, Balzer). Depois de secas, as amostras foram montadas em suportes metálicos ("stubs") e metalizadas com ouro (Silveira 1989), para então serem analisadas e registradas em Microscópio Zeiss (DSM 940).

\section{Resultados}

A tabela 2 apresenta um resumo dos resultados obtidos que serão descritos abaixo, para cada espécie analisada.

Pereskia bahiensis (“Pereskioideae”): inicialmente, a aréola apresenta-se com simetria bilateral pela formação de tricomas unisseriados multicelulares apenas do lado abaxial do meristema areolar (Figs. 10-12), originados da protoderme. Embora não tenha sido possível observar a zonação do meristema areolar, este apresentou uma região central constituída por células com citoplasma denso e em intensa atividade mitótica e uma região mais interna a esta, cujas células apresentam-se mais vacuoladas, indicando um estágio posterior de diferenciação (Fig. 13). 
Após este estágio, há formação de tricomas também no lado adaxial do meristema areolar, tornando a simetria da aréola radial (Figs. 14-15), com tricomas encontrados em toda região areolar. A partir deste estágio, foi possível notar duas situações: uma onde os tricomas são unisseriados multicelulares desde a base (Fig. 16) e outra onde a região basal apresenta um tecido, caracterizado como uma única estrutura com base multisseriada e uma região apical com várias fileiras de células independentes (Fig. 17).

Aréolas mais desenvolvidas apresentam espinhos no lado abaxial, retomando uma simetria bilateral e, posteriormente, há formação de primórdios foliares no lado adaxial do meristema areolar (Figs. 14, 18). Nas figuras 19 a 21, que exibem seções transversais do caule, onde a região areolar pode ser vista em seção longitudinal, é possível observar três primórdios foliares e seus respectivos traços foliares.

Todo o sistema de revestimento na região areolar está representado pela poliderme. O felogênio se instala em uma região subepidérmica, para formar a poliderme, mantendo ainda os tricomas (Fig. 22). Apenas na região do meristema areolar e nas regiões da base de espinhos e primórdios foliares não foi observada a presença da poliderme (Figs. 23-24).

Os espinhos formados a partir do meristema areolar (Fig. 15) apresentam base meristemática (meristema intercalar) e ápice com células alongadas, vacuoladas e esclerificadas (Figs. 23-24). Em seções transversais das regiões medianas e apicais dos espinhos não foram observados tecidos vasculares (Figs. 25-26). Cordões de procâmbio foram observados apenas na região basal dos espinhos, cujas células apicais já se encontravam esclerificadas (Fig. 23). 
Em microscopia eletrônica de varredura, foi possível observar que a superfície dos espinhos é lisa (Figs. 27-28).

Maihuenia patagonica (Maihuenioideae): As aréolas da região mais apical costumam apresentar ainda as folhas ligadas ao caule (Figs. 29-30). A formação de segmentos caulinares, a partir do meristema areolar, foi observada ao longo de todo o eixo principal em aréolas cujos espinhos já estavam diferenciados (Figs. 30-31).

A presença de tricomas nos lados adaxial, abaxial e também lateralmente ao meristema areolar (Figs. 30-32), sugere que, inicialmente, as aréolas apresentam simetria radial.

Com a formação dos espinhos, abaxialmente em relação ao meristema areolar, as aréolas adquirem uma simetria bilateral. Os espinhos ocupam sempre uma posição mais externa da região (Figs. 30-31), não tendo sido observada a presença desses em regiões mais centrais da aréola. Em aréolas mais jovens são visíveis, em geral, dois espinhos pequenos, mas em todas as aréolas já desenvolvidas, há sempre três espinhos (Figs. 30-31).

Semelhante ao observado em Pereskia bahiensis, todo o sistema de revestimento na região areolar está representado pela poliderme, exceto na região do meristema areolar, com os tricomas unisseriados multicelulares ainda presentes (Figs. 32-38). Não foi observada a estrutura multisseriada na base de tricomas como descrito em Pereskia bahiensis.

Os espinhos apresentam uma região apical bastante esclerificada com células alongadas e uma região basal cujas células apresentam uma 
distribuição radiada (provavelmente resultante da atividade do meristema intercalar) e não esclerificadas (Figs. 39-41). Não foi observado tecido vascular na base dos espinhos (Fig. 41). Em microscopia eletrônica de varredura, foi possível observar que a superfície dos espinhos é lisa, semelhante ao registrado em Pereskia bahiensis (Figs. 42-43).

Como o segmento caulinar de Maihuenia patagonica apresenta várias aréolas em uma mesma seção transversal, foi possível observar a rede de feixes vasculares resultantes da vascularização originada das folhas (Figs. 4445). Não foram observados cordões vasculares oriundos dos espinhos, ou seja, os espinhos não apresentam qualquer diferenciação de sistema vascular.

Opuntia dillenii (Opuntioideae): semelhante à Maihuenia patagonica, as aréolas de 0 . dillenii apresentam inicialmente simetria radial, e, posteriormente, assumem uma simetria bilateral (Figs. 46-48). Esta simetria bilateral está bem definida quando se observam os gloquídeos no lado adaxial do meristema areolar e os espinhos do lado abaxial (Figs. 47-49). Os tricomas, produzidos a partir da protoderme (Fig. 50), são unisseriados multicelulares (Fig. 51). Ademais não foi observada a estrutura multisseriada descrita em Pereskia bahiensis.

O primórdio de espinho apresenta uma região meristemática (meristema intercalar) em sua base, e as células do ápice são alongadas e vacuoladas (Figs. 52-53), se tornando esclerificadas quando mais desenvolvidas (Figs. 52, 54). Durante a diferenciação das células dos espinhos, ocorre uma nítida região que se estende por quase todo o espinho, formada pelas células esclerificadas e uma região basal, bastante reduzida, formada por células não 
esclerificadas (Fig. 54). Em espinhos já desenvolvidos, é possível observar que as células mais internas não se encontram esclerificadas (Figs. 48 e 54). Assim como em Pereskia bahiensis e Maihuenia patagonica, em microscopia eletrônica de varredura foi possível observar que os espinhos apresentam superfície lisa (Fig. 55).

Já os primórdios de gloquídeos apresentam apenas as células alongadas e vacuoladas no ápice, sem uma nítida camada de células meristemáticas na região basal (Figs. 56-57), além de apresentarem células em forma de farpas no sistema de revestimento, cobrindo toda extensão dos gloquídeos já desenvolvidos (Figs. 58-59). A partir de seções em série, foi possível comprovar a ausência de cordões vasculares próximos à base de espinhos e gloquídeos (Fig. 60).

Já na região mais apical do segmento areolar, é possível observar a poliderme subepidérmica. Contudo, esta se limita apenas à região periférica da aréola (Figs. 49, 54, 60-61). Nas regiões mediana e basal do segmento caulinar foi possível observar a mesma organização da região areolar presente nas aréolas da região apical. 
Tabela 2. Resultados obtidos na análise da região areolar das espécies do estudo.
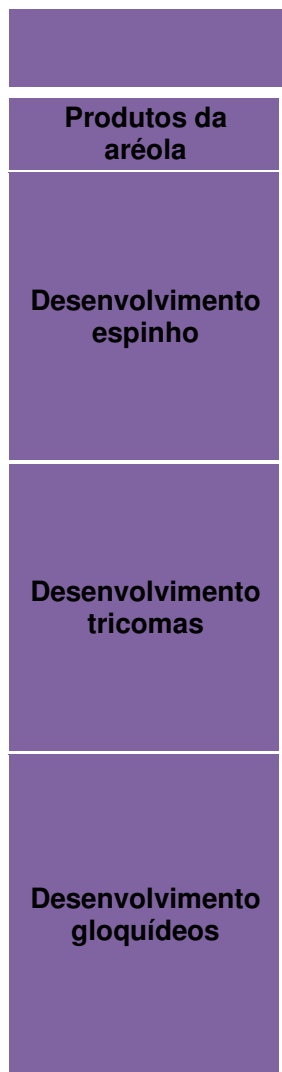

Poliderme
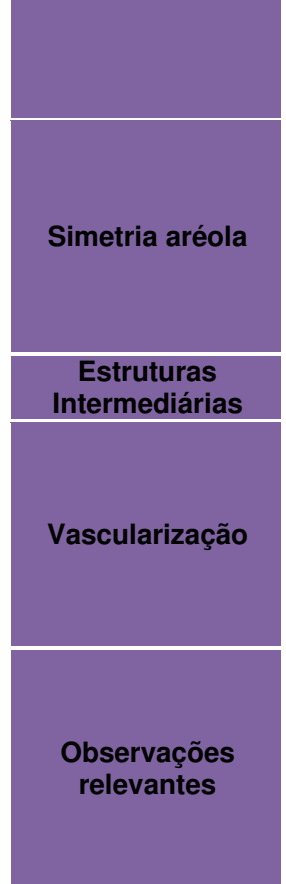

\begin{tabular}{|c|c|}
\hline Pereskia bahiensis & Maihuenia patagonica \\
\hline $\begin{array}{c}\text { Tricomas, espinhos e } \\
\text { primórdios foliares. }\end{array}$ & Tricomas e espinhos. \\
\hline $\begin{array}{c}\text { Possuem zona } \\
\text { meristemática na base e } \\
\text { ápice com células } \\
\text { alongadas, vacuoladas e } \\
\text { esclerificadas. Ausência de } \\
\text { células epidérmicas } \\
\text { semelhantes a farpas } \\
\text { ("barb-like cells"). }\end{array}$ & $\begin{array}{c}\text { Ausência de zona } \\
\text { meristemática na base dos } \\
\text { espinhos. Diferenciação } \\
\text { apical-basal dos espinhos } \\
\text { semelhantes às outras duas } \\
\text { espécies. Ausência de } \\
\text { células epidérmicas }\end{array}$ \\
\hline semelhantes a farpas ("barb- \\
like cells").
\end{tabular}

Unisseriados, multicelulares, formados a partir da protoderme e distribuídos em regiões onde há formação de tecido a partir de células subepidérmicas. subepidérmicas.

Geralmente a base se mantém interligada.

mantém interligada.

Ausente.

Poliderme de origem subepidérmica bem desenvolvida interna à aréola e em volta das aréolas mais maduras.

Bilateral, com espinhos ocorrendo na região abaxial e lateral da aréola, e tricomas em toda a região.

Ausente.
Cordões de procâmbio até
a base dos espinhos.

a base dos espinhos.

Presença de dois primórdios foliares produzidos pelo meristema areolar.
Provavelmente bilateral, devido aos 2-3 espinhos.

Poliderme presente na base dos tricomas, espinhos, em volta da aréola e fora dela.

\section{Ausente.}

Região areolar bastante vascularizada, possivelmente devido à presença de folhas na região. Nenhuma vascularização saindo dos espinhos.

Aréola extremamente menor que as demais. Poucos tricomas, espinhos já desenvolvildos desde o início.

\section{Opuntia dillenii (Ker Gawl.)} Haw.

Tricomas, espinhos e gloquídeos.

Presença de um espinho maior, e outro menor ou menos desenvolvido. Possuem zona meristemática na base e ápice com células alongadas e

vacuoladas. Ausência de células epidérmicas semelhantes a farpas ("barb-like cells").

Unisseriados, multicelulares, formados a partir da protoderme, e distribuídos em regiões onde há formação de tecido a partir de células subepidérmicas.

Menores que espinhos, com células alongadas e vacuoladas no ápice, e células epidérmicas mais alongadas na base em comparação com o ápice. Ausência de células meristemáticas na base. Células epidérmicas semelhantes a farpas ("barb-like cells") em toda a extensão do gloquídeo.

Poliderme presente em toda a aréola, na base dos tricomas, espinhos e gloquídeos, dentro e em volta da região areolar, e na aréola quando mais desenvolvida.

Bilateral, com meristema areolar produzindo espinhos na região abaxial, gloquideos circundando a aréola (radialmente), porém com

uma maior concentração na região adaxial, e tricomas cobrindo toda a região.

Ausente.

Vascularização até a base dos espinhos e gloquídeos. 


\section{Discussão}

A região areolar de Pereskia bahiensis, Maihuenia patagonica e Opuntia dillenii apresentam planos de simetria diferentes dependendo do grau de desenvolvimento da região. Esta situação já foi observada em outras espécies de Opuntioideae, Pereskioideae e Cactoideae (Boke 1944, 1951, 1952, 1953, 1954). O tipo de simetria encontrada em Pereskia bahiensis (inicialmente bilateral, com tricomas formados na face abaxial, se tornando radial com formação de tricomas em toda região e retomando a simetria bilateral em aréolas mais velhas com a produção dos espinhos) não foi relatada para nenhuma espécie da família. O padrão observado em Maihuenia patagonica e Opuntia dillenii, na qual as aréolas inicialmente radiais se tornam bilaterais com a formação dos espinhos, já foi observado para O. cylindrica (Boke 1944) e outras espécies de Cactoideae, como Coryphantha vivipara (Boke 1952) e também Pereskioideae, em Pereskia cubesis (Boke 1954). É importante registrar que essas alterações na simetria da região axilar foram observadas em outros grupos de Caryophyllales. Hernandes-Lopes (2010) relata a formação de tricomas inicialmente na face abaxial da axila foliar em Portulaca, para depois serem formados em toda a região axilar. Atualmente, Portulaca pertence ao clado ACP (Anacampseroteae + Cactaceae + Portulaca - Ogburn \& Edwards 2009). Portanto, a formação de estruturas na região da axila foliar se dá inicialmente na face abaxial e pode indicar um caráter presente no ancestral de ACP.

Nas três espécies do presente trabalho, a produção de espinhos se dá preferencialmente na região abaxial da aréola (entre a folha e o meristema 
areolar, ou gema axilar). O mesmo é observado em várias espécies da família (Boke 1944, 1951, 1952, 1955, 1957), porém há registro de espinhos sendo produzidos por toda volta do meristema areolar (Boke 1953, 1954, 1956, 1958). Tricomas são encontrados em toda a região areolar nas espécies estudadas, corroborando o observado na literatura para a família (Boke 1944, 1951, 1952, 1954, 1955, 1956, 1957, 1958; Freeman 1970; Gibson \& Nobel 1986). A presença de tricomas na axila foliar já foi relatada para grupos externos à Cactaceae, como Anacampseroteae e Portulaca (Hernandes-Lopes 2010), sendo uma das poucas sinapomorfias não moleculares para o clado ACP (Ogburn \& Edwards 2009).

Apenas Opuntia dillenii apresentou também gloquídeos na aréola, o que corrobora o esperado para Opuntioideae de acordo com a literatura (Boke 1944, Freeman 1970, Hamilton 1970, Gibson \& Nobel 1986, Anderson 2001, Arruda 2010). Freeman (1970) e Arruda (2010) relatam apenas a presença de gloquídeos nas aréolas de Opuntia basilaris, Opuntia microdasys e Opuntia rufida, sendo estes os únicos relatos da ausência de espinhos na estrutura. Boke (1944) relatou a presença de gloquídeos por toda região areolar de Opuntia cylindrica, porém $O$. dillenii apresentou estas estruturas preferencialmente na região adaxial, entre o meristema areolar e o segmento caulinar. Uma vez que gloquídeos são espinhos modificados (Boke 1944, Gibson \& Nobel 1986, Anderson 2001), essa diferença na ocorrência de gloquídeos pode ser apenas um reflexo do grau de diferenciação de espinhos nesta região, uma vez que são observados espinhos de diversos tamanhos e níveis de desenvolvimento numa mesma aréola em espécies de Cactoideae (Boke 1951, 1952, 1953; Gibson \& Nobel 1986) e Pereskioideae (Boke 1954). 
Os tricomas para as três espécies estudadas são unisseriados e multicelulares, situação bastante comum para a família (Boke 1944, 1951, 1952, 1954, 1955; Gibson \& Nobel 1986; Arruda 2010). Além disso, os tricomas têm origem da protoderme, corroborando o relatado na literatura, ainda que em muitos casos seja citada a formação de tricomas a partir da epiderme (Boke 1944, 1951, 1952). Entretanto, Boke (1954) já relata a origem protodérmica dos tricomas em Pereskia grandifolia. No caso de $P$. bahiensis, os tricomas em aréolas mais desenvolvidas apresentam um tecido em sua base, sendo caracterizado como uma estrutura única de base multisseriada e com uma região apical com fileiras independentes. Boke (1954) relata a ocorrência de divisões periclinais na base de alguns tricomas em $P$. grandifolia, mas o próprio autor considera isso como uma característica vestigial. Por outro lado, o mesmo autor em 1944 cita a formação de um "pseudotecido" a partir de tricomas em Opuntia cylindrica. É possível que a formação desta base multisseriada seja similar ao observado por Boke (1944), mesmo que a situação ocorra em grupos diferentes (Pereskioideae e Opuntioideae). Comparando os tricomas de Cactaceae aos que ocorrem em grupos próximos, algumas relações podem ser traçadas. Hernandes-Lopes (2010) descreve tricomas multicelulares e multisseriados em Portulaca, de origem protodérmica. Além disso, tricomas de Portulaca também sofrem lignificação desigual nas paredes celulares (Marinho \& Estelita 1996, Hernandes-Lopes 2010), situação já relatada para Cactaceae (Gibson \& Nobel 1986). Hernandes-Lopes (2010) infere que o ancestral do clado ACP deve possuir tricomas multisseriados na axila foliar, se tornando unisseriados em Cactaceae, sendo corroborado pelos dados obtidos no presente estudo. 
Internamente aos tricomas das espécies estudadas se encontra a poliderme, derivada da região subepidérmica, que recobre toda a região areolar, exceto o meristema, conforme esta se torna mais desenvolvida. Norman Boke relatou uma situação semelhante pela primeira vez em 1944, em Opuntia cylindrica, descrevendo a presença de súber, produzido a partir do felogênio hipodérmico e interno a espinhos e gloquídeos, formando uma proteção aos tecidos internos à aréola caso os espinhos sejam forçados para dentro da planta. Em trabalhos posteriores com Cactoideae, o autor relata a presença de felogênio na base de espinhos de Echinocereus reichenbachii, que se estende por toda a aréola (Boke 1951), e em Coryphantha vivipara descreve o felogênio derivado de células epidérmicas ou interno aos tricomas produzindo o súber que recobre toda a aréola exceto o meristema areolar (Boke 1952). Arruda (2010) cita a mesma situação em espécies de Opuntioideae, acreditando se tratar de uma poliderme, uma vez que o felogênio se divide produzindo apenas células do felema. É possível afirmar que a instalação do felogênio subepidérmico produzindo uma poliderme é uma situação comum para todos os grupos de Cactaceae. A região da axila foliar apresenta periderme bastante semelhante à poliderme encontrado para Cactaceae em espécies de Portulaca (Hernandes-Lopes 2010) e Anacampserotaceae (Ogburn \& Edwards 2009). Novamente, podemos inferir que um felogênio produzindo tecido de revestimento na região da axila foliar já estava presente no ancestral de ACP.

Os espinhos em desenvolvimento de Pereskia bahiensis e Opuntia dillenii apresentam as mesmas características, sendo formados, em parte, por uma zona meristemática intercalar (basal) produzindo células alongadas e 
esclerificadas para o ápice e células menores com pouca lignificação para a base. Essa estruturação do espinho foi descrita primeiramente para Opuntia cylindrica (Boke 1944) e observada para as demais espécies estudadas na família (Boke 1951, 1952, 1953, 1954, 1955, 1956, 1957, 1958; Gibson \& Nobel 1986). Apesar de não ser possível observar a zona meristemática em Maihuenia patagonica, uma organização radiada das células basais sugere que esta região é resultante da atividade do meristema intercalar que, neste caso, sofre uma rápida diferenciação dos tecidos. Vale ressaltar que nas outras duas espécies estudadas, esta situação de ausência da região meristemática só foi observada em espinhos situados em regiões basais dos segmentos caulinares e que, no caso de Maihuenia patagonica os espinhos já da região apical apresentam-se completamente diferenciados e desenvolvidos.

As células não lignificadas presentes na base dos espinhos foram interpretadas por Boke $(1944,1951,1952)$ como felogênio, responsáveis pela formação do então chamado súber em toda a região areolar. No presente estudo, observamos que os dois tecidos (poliderme e a base dos espinhos) têm origens distintas: a poliderme tem origem subepidérmica, enquanto que as células basais dos espinhos têm origem do meristema intercalar, sendo, portanto, uma extensão dos espinhos, ocorrendo de forma semelhante nos três exemplares estudados no presente trabalho.

Os espinhos de Pereskia bahiensis, Maihuenia patagonica e Opuntia dillenii possuem epiderme formada por células lisas (sem farpas) em toda a sua extensão, semelhante ao registrado por Boke (1951) em Echinocereus reichenbachii. Espinhos apresentando células com farpas apenas no ápice da 
estrutura foram relatados para Opuntia cylindrica (Boke 1944) e espinhos recobertos com células pequenas em forma de farpa foram encontrados em Austrocylindropuntia subulata e Opuntia monacantha (Arruda 2010).

A presença de células epidérmicas em forma de farpa em toda a extensão da estrutura vem sendo registrada em diversos representantes da subfamília Opuntioideae (Freeman 1970, Hamilton 1970, Boke 1980, Gibson \& Nobel 1986, Anderson 2001, Arruda 2010), caracterizando o tipo de espinho denominado de gloquideo. Embora na literatura se utilize a presença dessas células em forma de farpas para separar espinho de gloquídeo, vale ressaltar que o que vem caracterizando os gloquídeos não é a simples presença dessas células, mas a sua ocorrência em toda a extensão da estrutura.

Em termos de desenvolvimento, Boke (1944) e Hamilton (1970) mencionaram que os estágios iniciais do desenvolvimento de espinhos e gloquídeos são bastante semelhantes, sendo possível sua distinção após estágios posteriores, com os gloquídeos sendo menores que os espinhos, e que aparentemente a zona meristemática da base da estrutura se diferencia precocemente (Boke 1944). Esta diferenciação precoce da região meristemática basal foi observada em espinhos de Maihuenia patagonica, como mencionado anteriormente e nos gloquídeos de Opuntia dillenii, demonstrando que este não pode ser um caráter a ser utilizado na distinção dessas duas estruturas em Cactaceae.

Formas transicionais entre folhas e espinhos não foram observadas em nenhuma das espécies do presente estudo. Tais estruturas foram registradas em Opuntia cylindrica (Boke 1944), sendo bastante variáveis, mas em geral 
possuindo base foliar com constrição, como acontece na base das folhas de Opuntioideae e Pereskioideae (Boke 1944, 1980). Em Opuntia microdasys, além de ser observada situação semelhante a $O$. cylindrica, também foi registrada a presença de estômatos ao mesmo nível das demais células epidérmicas (Arruda 2010). Sendo, espinhos, folhas modificadas (Boke 1944, 1980; Gibson \& Nobel 1986), estruturas intermediárias servem como evidência desta origem, ainda que sua presença seja relatada apenas em espécies de Opuntioideae, um grupo relativamente derivado dentro da família.

A formação de primórdios foliares a partir do meristema areolar sem a formação de novos segmentos, como observado em Pereskia bahiensis, não foi relatado para nenhuma outra espécie estudada da família. Em outra espécie de Pereskia (Pereskia grandifolia) a situação descrita por Boke (1954) é a mais comum na família, havendo a produção de ramos curtos com folhas a partir do meristema areolar. Corroborando essa observação de Boke (loc. cit), Mauseth (1999) descreve a formação de ramos curtos em Maihuenia patagonica, que também apresenta folhas, semelhante ao observado no presente estudo. Desta forma, podemos dizer que a principal diferença entre a aréola de Pereskia bahiensis e de Maihuenia patagonica é o grau de redução do ramo formado a partir da gema axilar e que em ambos os casos, as folhas estão presentes em ramos curtos. Sendo a região areolar um ramo reduzido formado pela gema axilar, e espinhos folhas modificadas, não é de surpreender que algumas espécies na família apresentem folhas ou ramos se desenvolvendo a partir do meristema areolar (gema axilar). Analisando grupos próximos à Cactaceae, Hernandes-Lopes (2010) observou que a gema axilar de Talinum paniculatum produz inicialmente um par de profilos cujos ápices se apresentam 
esclerificados, e depois um único profilo, antes de continuar produzindo folhas comuns. O autor comparou a atividade da gema axilar com a do meristema areolar em Cactaceae descrita por Gibson \& Nobel (1986), onde espinhos são formados em seqüência alternada entre pares e estruturas únicas pelo meristema areolar. É possível também comparar os profilos às estruturas intermediárias observadas por Boke (1944) e Arruda (2010). Nyffeler \& Eggli (2010) citam tais profilos de Talinum, e os espinhos pequenos de Didieroideae (Didieriaceae) como características que podem indicar uma relação mais próxima entre esse grupo com o clado ACPT (Anacampseroteae, Cactaceae, Portulaca e Talinum - Nyffeler 2007). Nossos dados corroboram a análise de Hernandes-Lopes (2010), ao sugerir que a redução do ramo produzido pela gema axilar teria ocorrido no ancestral de ACPT, mas também presente em Didiereaceae, ainda que não se saiba com certeza qual a posição do grupo em Caryophylalles (Nyffeler \& Eggli 2010).

Nenhuma das espécies estudadas apresentou vascularização no interior dos produtos do meristema areolar, o que corrobora a literatura da família. Em Pereskia bahiensis, há a presença de cordões de procâmbio na base dos primórdios de espinhos, se formando a partir da zona meristemática intercalar (basal) unido ao traço de folha. Esse tipo de vascularização foi descrito em $O$. cylindrica (Boke 1944), e nessa mesma espécie autor também cita cordões vasculares se diferenciando no interior de formas intermediárias (folhas e espinhos). Há relatos da presença de sistema vascular próximo ao meristema areolar e primórdio de espinhos em Coryphantha vivipara, Pereskia grandifolia, Rhipsalis cassytha e Mammilaria lasiacantha (Boke 1952, 1954, 1955, 1958). É importante citar também que algumas espécies com folhas rudimentares não 
apresentam sistema vascular em seu interior (Boke 1951, 1955, 1957). Gibson \& Nobel (1986) consideram como possível explicação para a ausência de sistema vascular no interior dos espinhos a rápida esclerificação das células apicais da estrutura, que impediria a transmissão do sinal de diferenciação para as células centrais do espinho. Além disso, por apresentar células meristemáticas na base da estrutura, não haveria diferenciação celular na região. A vascularização das estruturas areolares é, portanto, relativamente variável na família, e a sua ausência deve ser reflexo de diferença na expressão gênica causada por fatores que não são necessariamente relacionados à rápida esclerificação ou presença de células meristemáticas.

Dessa forma, os resultados obtidos no presente estudo demonstram que a região areolar na família Cactaceae apresenta limitado número de variações na organização geral, e que o desenvolvimento dos produtos areolares é, de um modo geral, semelhante em todos os grupos com pequenas variações. Quando comparado aos grupos próximos da família, é possível encontrar semelhanças na região da axila foliar. As espécies do presente estudo foram selecionadas de acordo com a filogenia clássica para família. Uma vez que representantes de Pereskioideae apresentam folhas bastante desenvolvidas e persistentes, semelhante ao encontrado em outras eudicotiledôneas, muitos autores consideraram a redução foliar um caráter derivado (Britton \& Rose 1919, Gibson \& Nobel 1986). Desta forma, Pereskioideae seria mais basal, sendo Opuntioideae intermediária, por apresentar folhas pequenas e efêmeras e Cactoideae a mais derivada, com extrema redução foliar ou sua total perda. Com trabalhos mostrando que o gênero Maihuenia deveria ter sua própria subfamília (Wallace 1995, Nyffeler 2002), Maihuenioideae, com suas folhas 
pequenas e efêmeras, foi incluída como grupo-irmão de Opuntioideae, e essas duas subfamílias como grupo-irmão de Cactoideae. Griffith (2004) levantou questões evolutivas pouco exploradas para Cactaceae após fazer uma revisão dos estudos moleculares filogenéticos da família, buscando entender como seria o ancestral do grupo. Segundo o autor, todos os trabalhos, de um modo geral, indicavam que as relações dentro de Cactaceae não eram claras, assim como a posição da família em Caryophyllales, uma vez que estudos apontavam Cactaceae como estando inserida dentro de Portulacaceae, apresentando uma relação próxima com Anacampseros, Talinum e Talinella (Hershkovitz \& Zimmer 1997). Desta forma, Griffith (2004) considerou como consenso que o possível ancestral de Cactaceae não seria lenhoso e com folhas grandes, como se imaginava, mas sim suculento e possivelmente com folhas reduzidas. Assim, Pereskia não seria necessariamente basal na família apenas por apresentar folhas desenvolvidas.

Edwards et. al. (2005) propôs uma nova filogenia para Cactaceae, com base em dados moleculares. Este trabalho, que foi mais tarde completado por Edwards \& Donoghue (2006), apontou a parafilia de Pereskia como crucial para a resolução do grau de parentesco e diversificação da família. Sendo assim, o grupo mais basal dentro de Cactaceae seria formado pelas Pereskia encontradas principalmente no Caribe, México e Brasil, formando o Northern Pereskia clade, Rhodocactus ou clado A. As demais espécies de Pereskia, clado B, encontradas na América do Sul e Andes, formaria o grupo caulocacti com as demais subfamílias. A análise também mostrou que Maihuenioideae é grupo-irmão de Cactoideae e, junto com Opuntioideae, formam o core cacti. 
Em 2007, James Mauseth publicou um estudo com diferentes folhas de Cactoideae, inferindo quais genes equivalentes para cactos atuantes na morfogênese de folhas em de Arabidopsis poderiam ser reprimidos ou expressados de forma a resultar nas folhas diminutas observadas no grupo. Com análises anatômicas do desenvolvimento dessas folhas, 0 autor demonstra que, mesmo sendo pequenas e efêmeras, essas folhas apresentam um grau de complexidade muito grande, acreditando que são resultantes de uma restrição no programa de morfogênese da folha. Ao analisar seus dados juntamente com a filogenia de Cactoideae feita por Nyffeler (2002), em que vários gêneros com lâminas foliares aparecem bastante separados dentro do clado Cactoideae, o autor acredita que, estando essa filogenia correta, Cactoideae teria se diversificado enquanto apresentava folhas complexas e, assim, a restrição no programa de morfogênese das folhas teria ocorrido repetidamente na subfamília.

Em 2008, uma nova síntese de trabalhos foi feita buscando posicionar Pereskia dentro de Cactaceae (Griffith 2008). Uma vez que trabalhos anteriores apontam a família fortemente relacionada à Anacampseros, Grahamia, Portulaca, Talinum e Talinella (todas pertencentes à Portulacaceae), o hábito arbóreo, caule lenhoso e folhas não suculentas de Pereskia seria uma reversão, uma vez que Portulacaceae apresenta, em geral, folhas suculentas e hábito herbácio. Um estudo recente com folhas de Opuntioideae indica que Pereskiopsis, Austrocylindropuntia e Quiabentia, gêneros classicamente considerados basais para subfamília por apresentarem, entre outras características, folhas persistentes, são derivados, e que Maihueniopsis, que possui folhas decíduas e curtas, seria a mais basal (Griffith 2009). Com isso, há 
mais uma evidência que a redução foliar em Cactaceae deve ter ocorrido várias vezes dentro do grupo.

Ainda que as filogenias moleculares atuais para a família sejam bem robustas, dados da morfologia ainda causam discussão. Por exemplo, a parafilia de Pereskia, indicada pelos dados moleculares, trás pelo menos um problema. Sendo o ancestral comum do clado ACPT herbáceo com folhas pequenas, Pereskia seria arbórea, lenhosa e com folhas expandidas se: 1houvesse uma reversão no ancestral de Cactaceae, e a condição herbácea com folhas pequenas fosse retomada no clado core cacti ou; 2- ocorresse a reversão para hábito arbóreo nas Pereskia clado $A$ e clado $B$ independentemente. Recentemente, um estudo foi feito apontando características anatômicas que suportam a relação entre os grupos dentro de Portulacineae, como a instalação precoce da periderme no caule, a presença de drusas, células ou cavidades mucilaginosas, grau de desenvolvimento das folhas entre outros (Ogburn \& Edwards 2009). Contudo, é importante que as próximas filogenias considerem também dados morfológicos integrados aos moleculares, a fim de que se possa supor da melhor forma as relações entre os grupos e como se deu a evolução da família.

Considerando as filogenias atuais de Cactaceae, as três espécies estudadas são representantes de diferentes grupos derivados dentro da família, sendo Pereskia bahiensis inclusa no clado B de Edwards \& Donoghue (2006), basal dentro do grupo monofilético denominado de caulocacti. Assim, é possível afirmar com bastante convicção que os indícios da origem da região 
areolar a partir da axila foliar não devem estar em representantes dentro da família, mas possivelmente em algum dos grupos-irmão de Cactaceae.

Neste sentido, Nyffeler \& Eggli (2010) publicaram uma nova forma de classificação de famílias para o grupo Portulacineae, onde são reconhecidas oito famílias incluindo Portulacaceae, Basellaceae, Didieraceae e Cactaceae. Neste trabalho, que resultou em várias mudanças dentro do grupo Portulacineae, incluindo a descrição da família Anacampserotaceae, os autores descrevem semelhanças encontradas na região da axila foliar de Cactaceae, Didiereoideae, Anacampseros e Portulaca. Enquanto Didiereoideae apresenta axila foliar semelhante às aréolas de Cactaceae, sendo as únicas diferenças a presença de espinhos menores e de número definido, e a ausência de tricomas na região, Anacampseros e Portulaca não possuem espinhos, mas ainda sim possuem emergências na região, além de tricomas de origem da gema axilar. Os autores acreditam que as emergências presentes em Anacampseros e Portulaca são vestígios de um ramo condensado na axila de folhas que, junto com a aréola, é uma sinapomorfia em potencial para um subclado de Portulacineae. Hernandes-Lopes (2010), ao observar profilos em Talinum paniculatum, cuja anatomia é semelhante a das estruturas intermediárias em Cactaceae, tendo como base o descrito por Nyffeler \& Eggli (2010), sugere que o ancestral para $\mathrm{ACPT+Didiereaceae} \mathrm{apresentaria} \mathrm{ramo} \mathrm{reduzido,} \mathrm{que} \mathrm{seria}$ perdido em Portulacaceae e Anacampserotaceae; os tricomas, no entanto, teriam surgido no ancestral de ACP. Uma vez que os trabalhos recentes indicam que a origem da aréola amplamente descrita em Cactaceae deve ser vista em grupos como Didiereaceae, propomos que os próximos trabalhos a serem realizados buscando informações sobre a origem da região areolar e de 
como se deu a transformação de seus produtos (folhas e espinhos) devem ser focados em outros representantes da subordem Portulacineae. Acreditamos que, com base em tudo que já foi descrito e nos resultados obtidos no presente estudo, para que as Cactaceae estejam plenamente estudadas, ainda é necessário verificar o clado A proposto por Edwards \& Donoghue (2006), e que estudos como este são de extrema importância para o entendimento da história evolutiva do grupo.

\section{Conclusão}

De um modo geral, a análise anatômica da região areolar das espécies estudadas se apresentou semelhante ao já descrito para as demais espécies da família. Como dados inéditos podemos citar: 1) a presença de cordões de procâmbio na base dos espinhos de Pereskia bahiensis, uma vez que a vascularização foi apenas relatada próxima aos espinhos, e não até sua base; 2) A estrutura do espinho de Maihuenia patagonica, no qual não se observa meristema intercalar mesmo em aréolas encontradas no ápice do ramo, que indica uma possível falha na delimitação entre espinho e gloquídeo.

Gloquídeos são descritos como espinhos modificados que apresentam células em forma de farpa na epiderme ao longo de toda a estrutura e meristema intercalar ativo por pouco tempo. No caso da $M$. patagonica onde os espinhos não apresentam farpas, mas apresentam uma diferenciação precoce do meristema intercalar, esta estrutura poderia ser interpretada como uma condição intermediária entre a forma de um gloquídeo (espinho modificado, 
típico de Opuntioideae) e um espinho (estrutura presente na aréola de todas as Cactaceae). Outro exemplo que demonstra a fragilidade da delimitação de gloquideos é a presença, em algumas espécies de Opuntioideae e Cactoideae, de espinhos com farpas na região apical. Diante desses estados de caracteres, sugerimos que sejam realizados mais estudos sobre desenvolvimento dessas estruturas.

Durante nossas análises, notamos que a organização básica da região areolar nas espécies estudadas apresentava o mesmo padrão básico, como a presença de poliderme, a formação dos tricomas e o desenvolvimento dos espinhos. Concluímos que tais caracteres são, portanto, bastante conservados no grupo, ou seja, provavelmente a história evolutiva desses caracteres teve início anterior ao surgimento do grupo. Esta conservação do caráter causou surpresa, uma vez que sendo uma sinapomorfia de Cactaceae, os diferentes estados de caracteres deveriam estar representados dentro do grupo. É importante ressaltar que nos últimos anos, características da família que eram consideradas inquestionáveis, hoje se mostram diferentes do que se imaginava e requerem estudos mais profundos como, por exemplo, a redução foliar em Cactoideae, que possivelmente ocorreu diversas vezes em diferentes tribos. Pereskia também, considerada basal para família por décadas, hoje pode ser ainda mais derivada que representantes globosos de Cactoideae. Contudo, quando analisamos os trabalhos com grupos relacionados à subordem a qual Cactaceae está inserida (Portulacineae), notamos semelhanças nas estruturas presentes na axila foliar, como a periderme, tricomas e a produção de profilos esclerificados. 
Assim, considerando os resultados obtidos no presente trabalho, acreditamos que estudos que buscam explicar a origem da região areolar em Cactaceae devem ser feitos em grupos relacionados dentro de Portulacineae, como Portulacaceae, Anacampserotaceae e Didiereaceae. Contudo, destacamos que com as novas filogenias moleculares mostrando diferentes posicionamentos dentro de Cactaceae, ainda são necessários estudos com grupos hoje considerados basais, para que este caráter seja compreendido no grupo. 


\section{Resumo}

Uma das características marcantes na família Cactaceae A.L. de Jussieu é a presença de aréolas no caule, consideradas ramos altamente reduzidos. A estrutura e o desenvolvimento da região areolar foram temas de vários trabalhos, tendo sido analisados representantes das subfamílias Pereskioideae, Opuntioideae e Cactoideae. De um modo geral, os trabalhos relatam a ocorrência de tricomas e espinhos, estruturas intermediárias entre espinhos e folhas e os padrões de vascularização da região areolar. Sendo assim, o estudo da aréola em Cactaceae ainda requer investigações anatômicas, principal motivo que impulsionou o desenvolvimento deste trabalho que consiste em analisar a estrutura e a vascularização da região areolar em grupos de Cactaceae que apresentam folhas. Para tanto, foram selecionadas as seguintes espécies: Pereskia bahiensis Gürke (Pereskioideae), Maihuenia patagonica (Phil.) Britton \& Rose (Maihuenioideae) e Opuntia dillenii (Ker Gawl.) Haw. (Opuntioideae). O estudo envolveu análise em microscopias óptica e eletrônica de varredura, considerando aspectos relativos às estruturas presentes na região da aréola como tricomas, espinhos e folhas e descrevendo a organização geral dos tecidos e a vascularização da aréola, através de cortes seriados transversais e longitudinais. Como resultados, podemos pontuar a presença de cordão vascular na base de espinhos de $P$. bahiensis; precoce diferenciação da zona meristemática intercalar em espinhos de $M$. patagonica, e as muitas semelhanças com a região da axila foliar em famílias relacionadas a Cactaceae. Concluímos, portanto, que a aréola possui organização conservada dentro de Cactaceae e que futuros estudos buscando entender a origem da região areolar devem ser focados no grupo Rhodocactus (basal de Cactaceae), e também em outras famílias dentro de Portulacineae.

Palavras-chave: Cactaceae, Opuntia, Pereskia, Maihuenia, aréola, axila foliar, Portulacineae. 


\section{Abstract}

One of the remarkable features of Cactacaeae A. L. de Jussieu is the presence of areoles in the steam, considered very short shoots. Many studies of the structure and development of the areole were made with species of Pereskioideae, Opuntioideae and Cactoideae. In general, these studies describe the presence of trichomes and spines, transitional forms between spines and leaves and vascular patterns of the areole region. Thus, the study of areole in Cactaceae requires anatomical investigations, propelling the development of this work. Our study consists in analyzing the structure and vascularization of the areolar region in groups of Cactacea that present leaves, and the select speacies were: Pereskia bahiensis Gürke (Pereskioideae), Maihuenia patagonica (Phil.) Britton \& Rose (Maihuenioideae) and Opuntia dillenii (Ker Gawl.) Haw. (Opuntioideae). The analyzes were made with optical and eletronic scanning microscopy, considering aspects related to structures present in the areole, like trichomes, spines and leaves, and describing the general organization of the tissues and vascularization of the areole, through transverse and longitudinal seriate sections. As results, we can point out the presence of a procambial strand in the base of the spines in $P$. bahiensis, the early differentiation of the meristematic intercalary zone in spines of $M$. patagonica, and the many similarities between areole and the leaf axil in families related to Cactaceae. We conclude the areole organization is conserved inside Cactaceae, and that future studies aiming the understanding of the origin of the areolar region should be focused in Rhodocactus (basal to Cactaceae), and also in groups inside Portulacineae.

Key words: Cactaceae, Opuntia, Pereskia, Maihuenia, areole, leaf axil, Portulacineae. 


\section{Referências Bibliográficas}

Anderson, E. F. 2001. The Cactus Family. TimberPress, Portland, Oregon, US.

Arruda, E. 2010. Histogênese de Segmentos Caulinares de Espécies de Opuntioideae (Cactaceae). Tese de Doutorado. Universidade de São Paulo, São Paulo.

Boke, N.H. 1941. Zonation in the Shoot Apices of Trichocereus spachianus and Opuntiacylindrica. American Journal of Botany 28: 656-664.

Boke, N.H. 1944. Histogenesis of the Leaf and Areoles in Opuntia cylindrica. American Journal of Botany 31: 299-316.

Boke, N. H. 1951. Histogenesis of the Vegetative Shoot in Echinocereus. American Journal of Botany 38: 23-38.

Boke, N.H. 1952. Leaf and Areole Development in Coryphantha. American Journal of Botany 39: 134-145.

Boke, N.H. 1953. Tubercle Development in Mammilaria heyderi. American Journal of Botany 40: 241-247.

Boke, N.H. 1954. Organogenesis of the Vegetative Shoot in Pereskia. American Journal of Botany 41: 619-637.

Boke, N.H. 1955. Development of the Vegetative Shoot in Rhipsalis cassytha. American Journal of Botany 42: 1-10.

Boke, N.H. 1956. Developmental Anatomy and the Validity of the Genus Bartschella. American Journal of Botany 43: 819-827.

Boke, N.H. 1957. Comparative Histogenesis of the Areoles in Homalocephala and Echinocactus. American Journal of Botany 44: 368-380. 
Boke, N.H. 1958. Areole Histogenesis in Mammilaria lasiacantha. American Journal of Botany 45: 473-479.

Boke, N.H. 1960. Anatomy and Development in Solisia. American Journal of Botany 47: 59-65.

Boke, N.H. 1961. Areole Dimorphism in Coryphantha. American Journal of Botany 48: 593-603.

Boke, N.H. 1980. Developmental Morphology and Anatomy in Cactaceae. Bioscience 30: 605-610.

Britton, N. L. \& Rose, J. N. 1919. The Cactaceae. Carnegie Institution, New York.

Edwards, E. J. \& Donoghue, M. J. 2006. Pereskia and the origin of cactus life form. The American Naturalist 167: 777-793.

Edwards, E. J.; Nyffeler, R.; \& Donoghue, M. J. 2005. Basal cactus phylogeny: implications of Pereskia (Cactaceae) paraphyly for the transition to the cactus life form. American Journal of Botany 92: 1177-1188.

Freeman, T. P. 1970. The Developmental Anatomy of Opuntia basicalis II. Apical Meristem, Leaves, Areoles, Glochids. American Journal of Botany 57: 616-622.

Gibson, A. C. \& Nobel, P. S. 1986. The Cactus Primer. Harvard University Press, London.

Griffith, M. P. 2004. What did the first cactus look like? An attempt to reconcile the morphological and molecular evidence. Taxon 53: 493-499.

Griffith, M. P. 2008. Pereskia, Portulacaceae, photosynthesis, and phylogenies: implications for the early Cactaceae. Haseltonia 14: 37-45. 
Griffith, M. P. 2009. Evolution of leaf and habit characters in Opuntioideae (Cactaceae): reconstruction of ancestral form. Bradleya 27: 49-58.

Hamilton, M. W. 1970. The Comparative Morphology of Three Cylindropuntias. American Journal of Botany 57: 1255-1263.

Hernandes-Lopes, J. 2010. Desenvolvimento da folha e axila foliar em Portulacaceae e Talinaceae: homologias primárias no clado ACPT. Dissertação de Mestrado. Universidade de São Paulo, São Paulo.

Hershkovitz, M. A. \& Zimmer, E. A. 1997. On the evolutionary origins of the cacti. Taxon 46: 217-232.

Johasen, D. A. 1940. Plant Microtechnique. 3a ed. Paul B. Hoeber, Inc, New York.

Judd, W.; Campbell, C.; Kellogg, E.; Stevens, P. \& Donogue, M. 2002. Plant Systematics - A Phylogenetic Approach. 2a ed. Sinauer Associates, Sunderland.

Kraus, J. E. \& Arduin, M. 1997. Manual Básico de Anatomia Vegetal. Ed. Universidade Rural, Rio de Janeiro.

Marinho, T. C. \& Estelita, M. E. M. 1996. Anatomia e ultra-estrutura foliar das Portulacaceae da Serra do Cipó, Minas Gerais. Revista Brasileira de Botânica 19: 61-65.

Mauseth, J. D. 1999. Anatomical adaptations to xeric conditions in Maihuenia (Cactaceae), a relictual, leaf-bearing cactus. Journal of Plant Research 112: $307-315$.

Mauseth, J. D. 2007. Tiny but complex foliage leaves occur in many "Leafless" cacti (Cactaceae). International Journal of Plant Sciences 168: 845-853. 
Mauseth, J. \& Landrum, J. V. 1997. Relictual vegetative anatomical characters in Cactaceae: the genus Pereskia. Journal of Plant Research. 110: 5564.

Nyffeler, R. 2002. Phylogenetic relationships in the cactus family (Cactaceae) based on evidence from trnK/matK and trnL-trnF sequences. American Journal of Botany 89: 312-326.

Nyffeler, R. 2007. The closest relatives of cacti: insights from phylogenetic analyses of chloroplast and mitochondrial sequences with special emphasis on relationships in the tribe Anacampseroteae. American Journal of Botany 94: 89-101.

Nyffeler, R. \& Eggli, U. 2010. Disintegrating Portulacaceae: a new familial classification of the suborder Portulacineae (Caryophylalles) based on molecular and morphological data. Taxon 59: 227-240.

Ogburn, R. M. \& Edwards, E. J. 2009. Anatomical variation in Cactaceae and relatives: trait lability and evolutionary innovation. American Journal of Botany 96: 391-408.

Ruzin, S. E. 1999. Plant Microtechnique and Microscopy. Oxford University Press, New York.

Salgado, T. T. \& Mauseth J. D. 2002. Shoot Anatomy and Morphology. In: Nobel, P. S. Cacti: Biology and Uses. University of California Press, Los Angeles.

Silveira, M. 1989. Preparo de Amostras Biológicas para Microscopia Eletrônica de Varredura. In: Souza, W. (ed.). Manual sobre técnicas básicas em microscopia eletrônica. v.1. Sociedade Brasileira de Microscopia Eletrônica, Rio de Janeiro. 
Souza, V. C. \& Lorenzi, H. 2005. Botânica Sistemática: Guia llustrado para Identificação das Famílias de Angiospermas da Flora Brasileira, Baseado em APGII. Instituto Plantarum, Nova Odessa.

Stevens, P. F. 2001. Agiosperm Phylogeny Website. Versão 9, Junho 2008. Website http://www.mobot.org/MOBOT/research/APweb/ [Acessado em Julho, 2010].

Wallace, R. S. 1995. Molecular systematic study of the Cactaceae: using chloroplast DNA variation to elucidate cactus phylogeny. Bradleya 13: 112.

Wallace, R. S. \& Gibson, A. C. 2002. Evolution and Systematics in Nobel, P. S. Cacti: Biology and Uses. University of California Press, Los Angeles. 
Capa: Primórdio de espinho de Opuntia dillenii. 

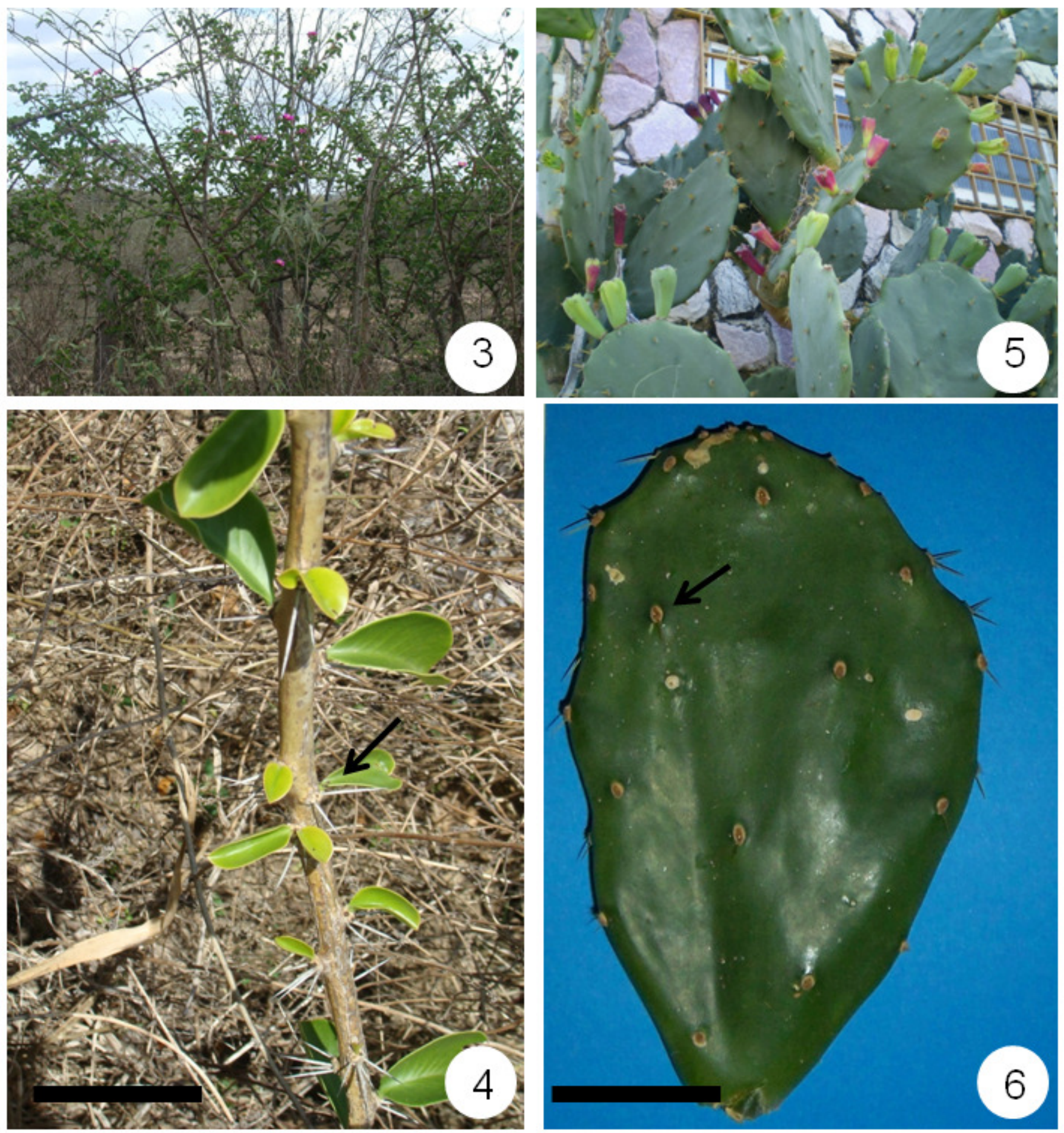

Figuras 3-6: Organizaçäo geral de Pereskia bahiensis e Opuntia dillenii. Figs. 3-4: Vista geral de P. bahiensis. Fig. 4: Detalhe do ramo, com folh as sain do da aréola (seta). Figs. 5-6: Vista geral de 0 . dilienii. Fig. 6: Detalhe do ramo em forma de palma, com aréolas presentes ao longo de toda a estrutura (seta). Barras: $4 \mathrm{~cm}$ (4) e $5 \mathrm{~cm}$ (6). 

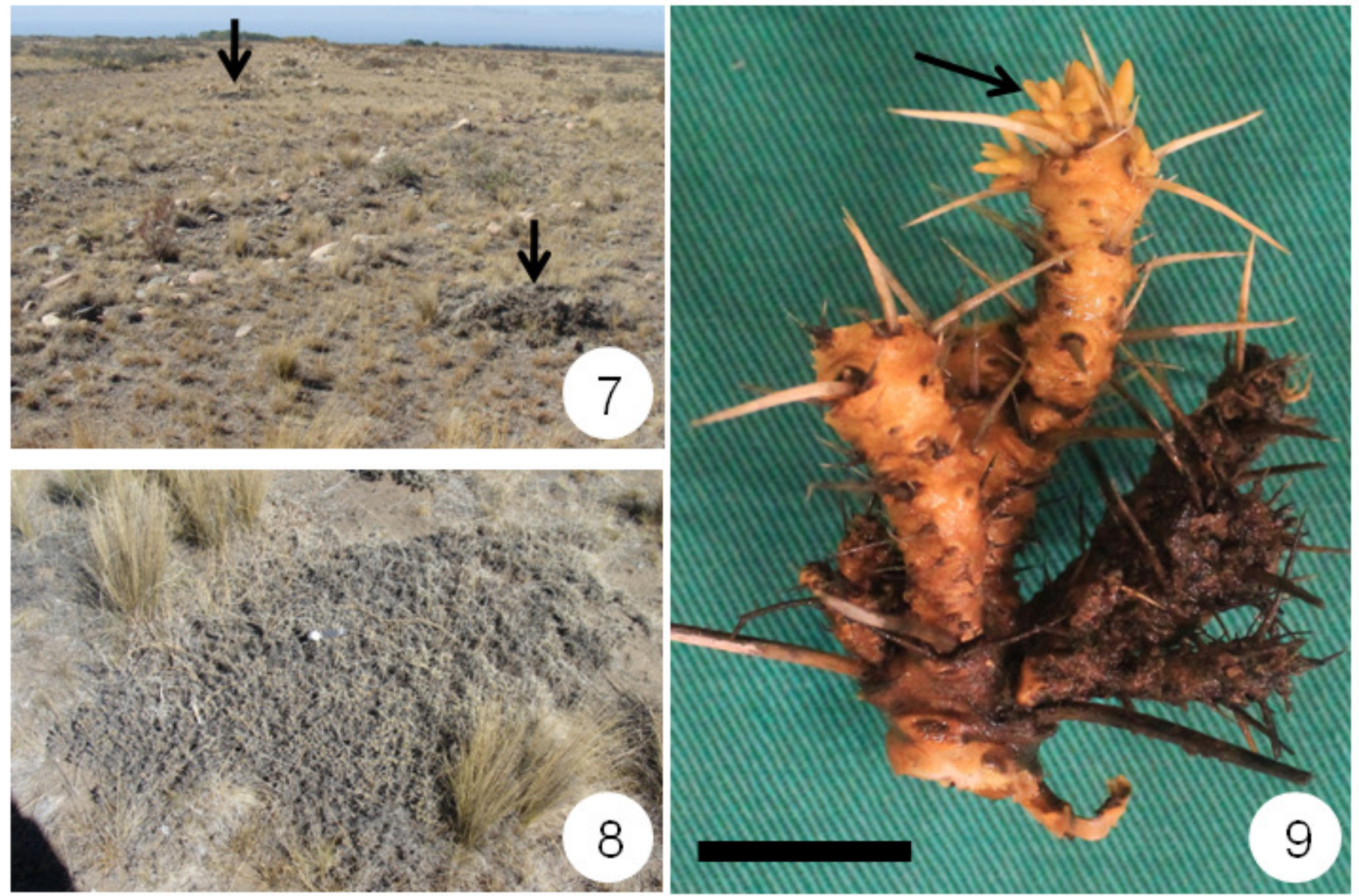

Figuras 7-9: Organizaçấo geral de Maihuenia patagonica. Fig. 7: Local de coleta e in dicaçấo das populaçôes (setas). Fig. 8: Vista geral de uma população. Fig. 9: Detalhe dos ramos, com aréolas presentes ao longo de toda a estrutura., e ramos com folhas no ápice do segmento (seta). Barra: $3 \mathrm{~cm}$. 

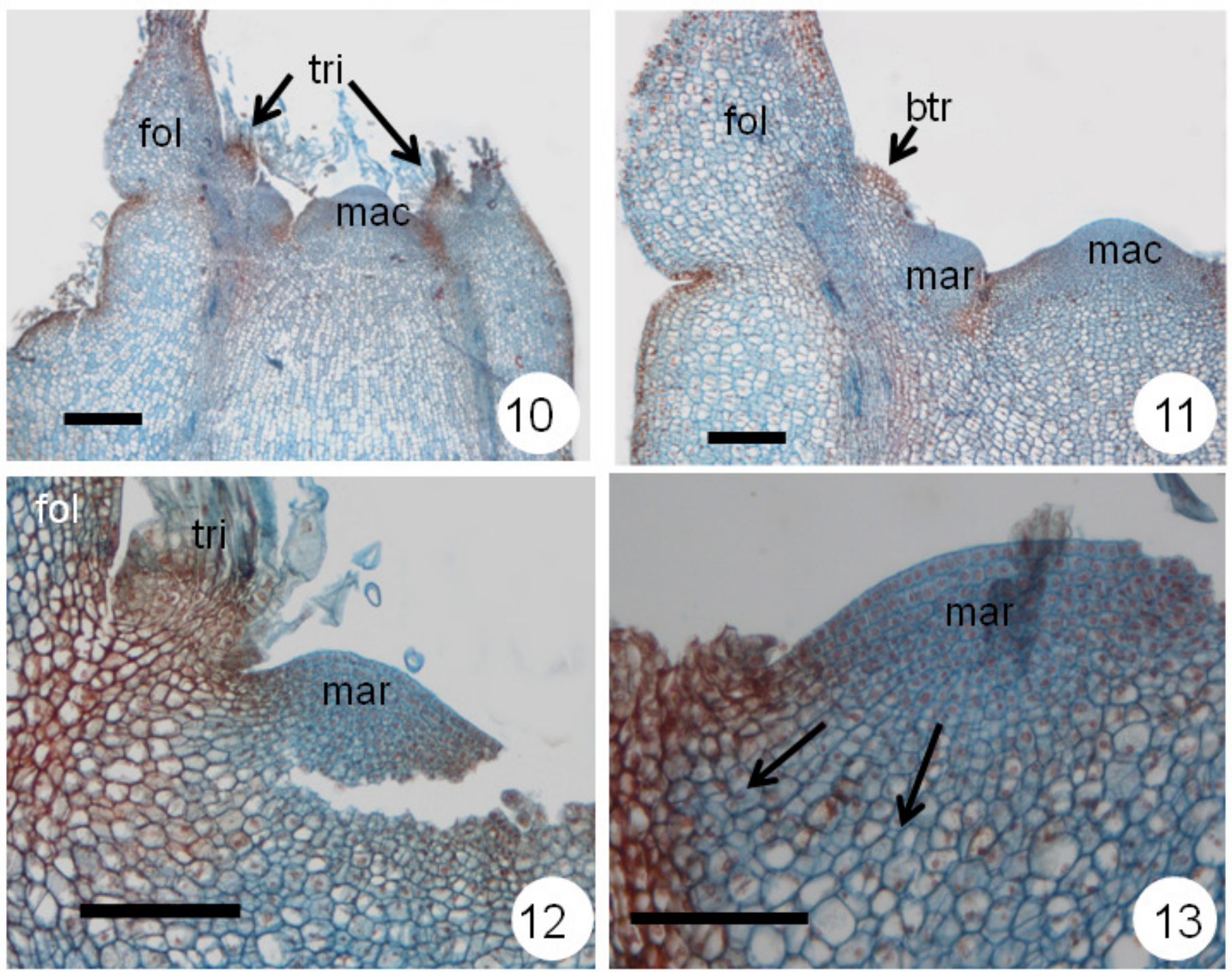

Figuras 10-13: Secçẩo longitudinal de Pereskia bahiensis. Figs. 10-11: Ápice caulinar (mac) produz folha (fol) e meristema areolar (mar) na axila foliar e já houve a formaçäo de tricomas (tri) na regiẫo abaxial do meristema, torn an do a simetria da aréola bilateral (btr - base dos tricomas). Figs. 12-13: Detalhe da aréola. Fig. 12: Meristema areolar e tricomas produzidos na regiẫo abaxial da aréola. Fig. 13: Detalhe meristema areolar, mostran do região com inten sa atividade mitótica e zona com células já diferenciadas (setas in dican do direçẩo da diferenciaçấo). Barras: $340 \mu \mathrm{m}$ (10), $160 \mu \mathrm{m}$ (11), $250 \mu \mathrm{m}$ (12) e $80 \mu \mathrm{m}$ (13). 

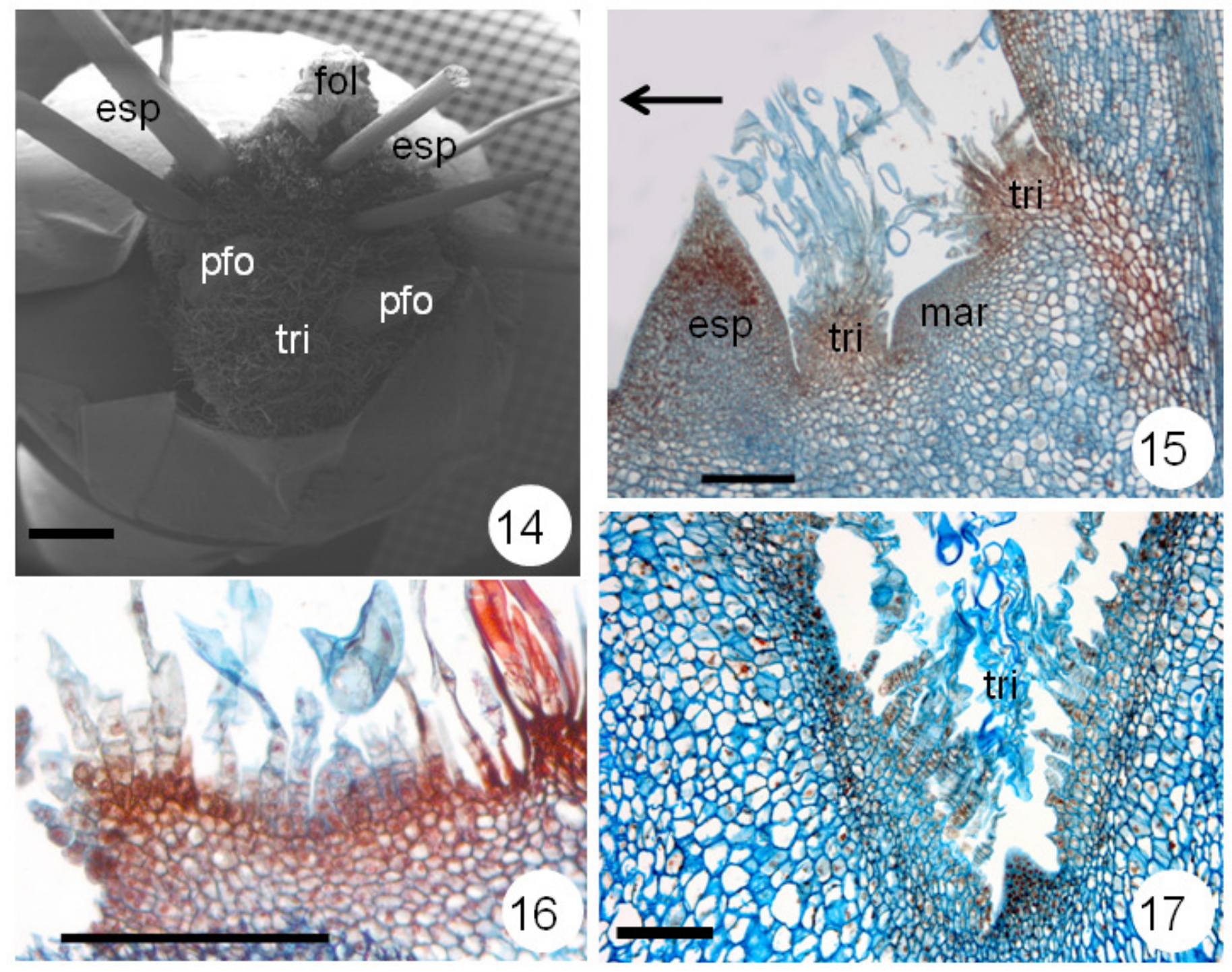

Figuras 14-17: Pereskia bahiensis. Fig. 14: Microscopia eletrônica de varredura da regiâo areolar, mostran do matriz de tricomas (tri), espinhos (esp) próximos à folha (fol) de origem do meristema apical, e primórdios foliares (pfo) sendo produzidos pelo meristema areolar, torn ando a aréola bilateral. Figs. 15-17: Secçôes Iongitu dinais da regiẫo areolar. Fig. 15: Meristema areolar envolvido por tricomas, e primórdio de espinho na face abaxial da aréola. A seta indica a posiçẫo da folha,originada do meristema apical, em relaçâo a imagem. Figs. 16-17: Tricomas, que podem ser en contrados unisseriados e multicelulares (16) ou formando uma base multisseriada (17). Barras: $1 \mathrm{~mm}$ (14), $160 \mu \mathrm{m}$ (15), $250 \mu \mathrm{m}$ (16) e $200 \mu \mathrm{m}$ (17). 

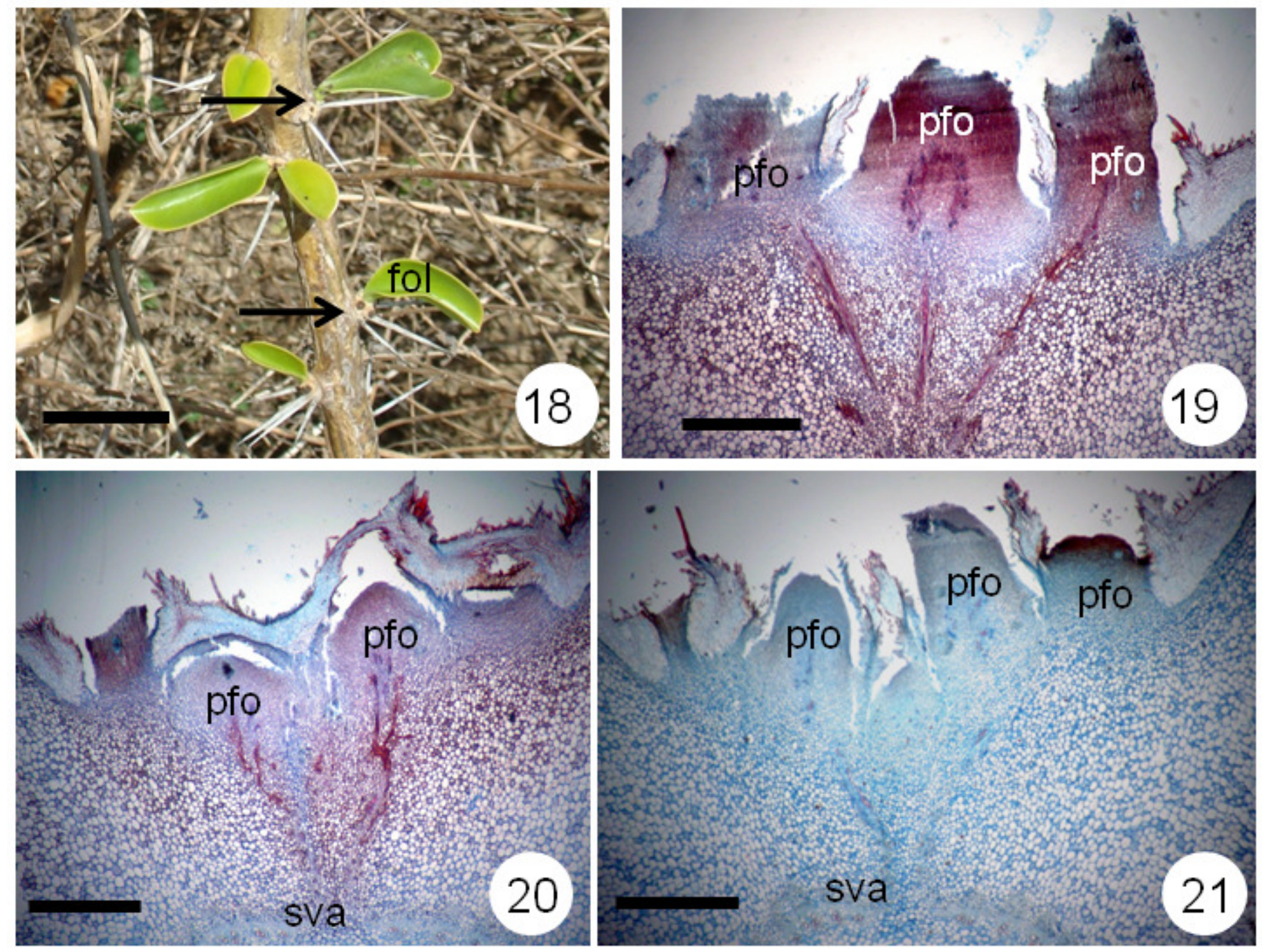

Figuras 18-21: Pereskia bahiensis. Fig. 18: Detalhe do ramo com folhas (fol) que saem do interior da aréola (setas). As folhas originadas do meristema apical já foram destacadas do ramo. Figs. 19-21: Secçôes longitudinais da região areolar e transversais do caule (notar sistema vascular-sva), em série, mostrando primórdios foliares (pfo) produzidos pelo meristema areolar, com traços foliares. Barras: $6 \mathrm{~cm}$ (18) e $960 \mu \mathrm{m}(19-21)$. 

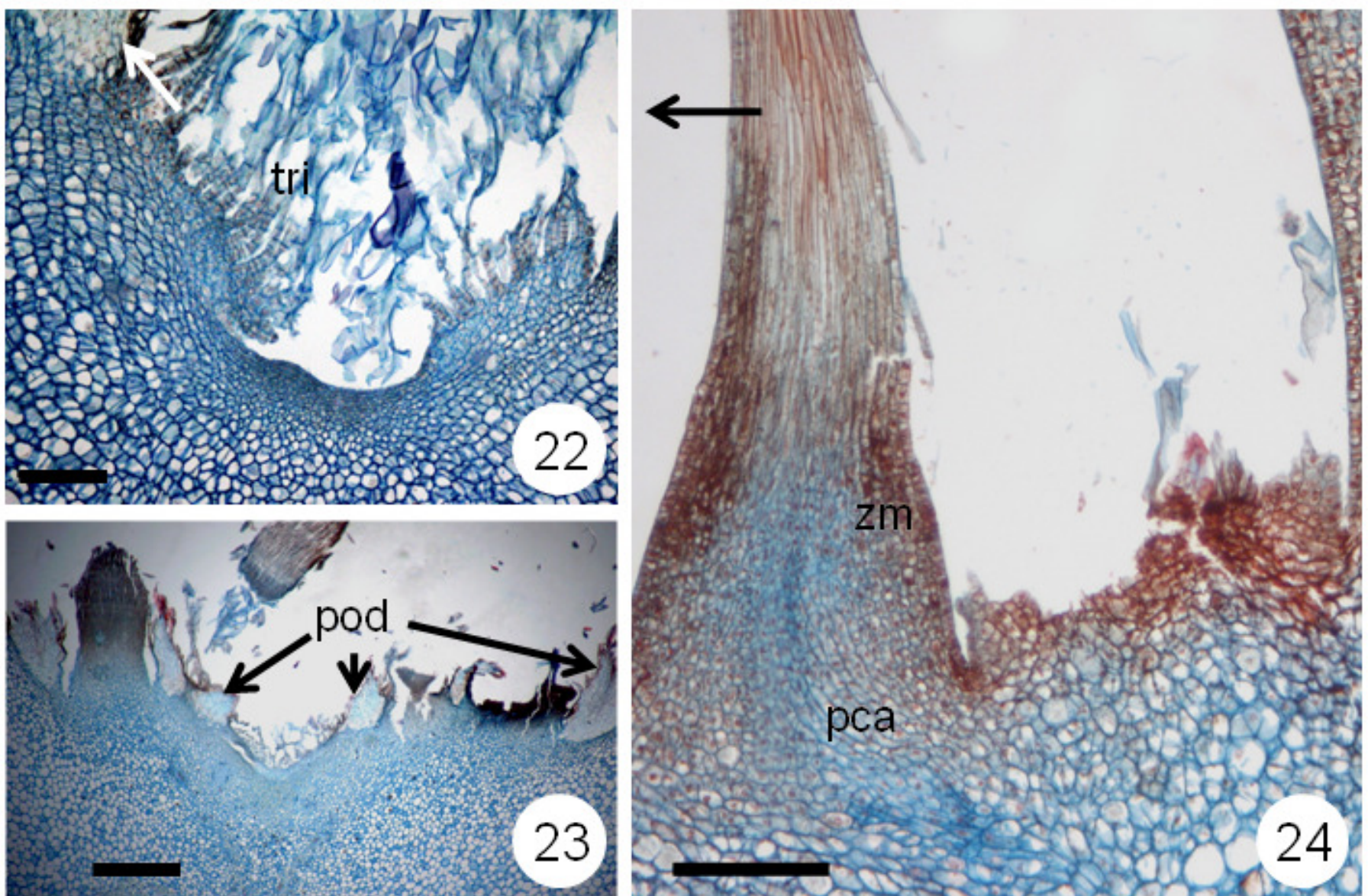

Figuras 22-24: Secçôes longitudinais da aréola de Pereskia bahiensis. Fig. 22: Poliderme (seta) presente na regiâo periférica da aréola. Fig. 23: Presença da poliderme (setas) em toda a regiăo areolar, com exceçăo da regiâo basal do espinho. Fig. 24: Primórdio de espinho, com base meristemática (zme), procâmbio (pca) na base da estrutura, e no ápice células alongadas e esclerificadas, além de possúir epiderme lisa. Seta da figura 24 indicando a posiça̋o da folha em relaçăo a imagem. Barras: $160 \mu \mathrm{m}(22$ e 24) e $680 \mu \mathrm{m}(23)$. 

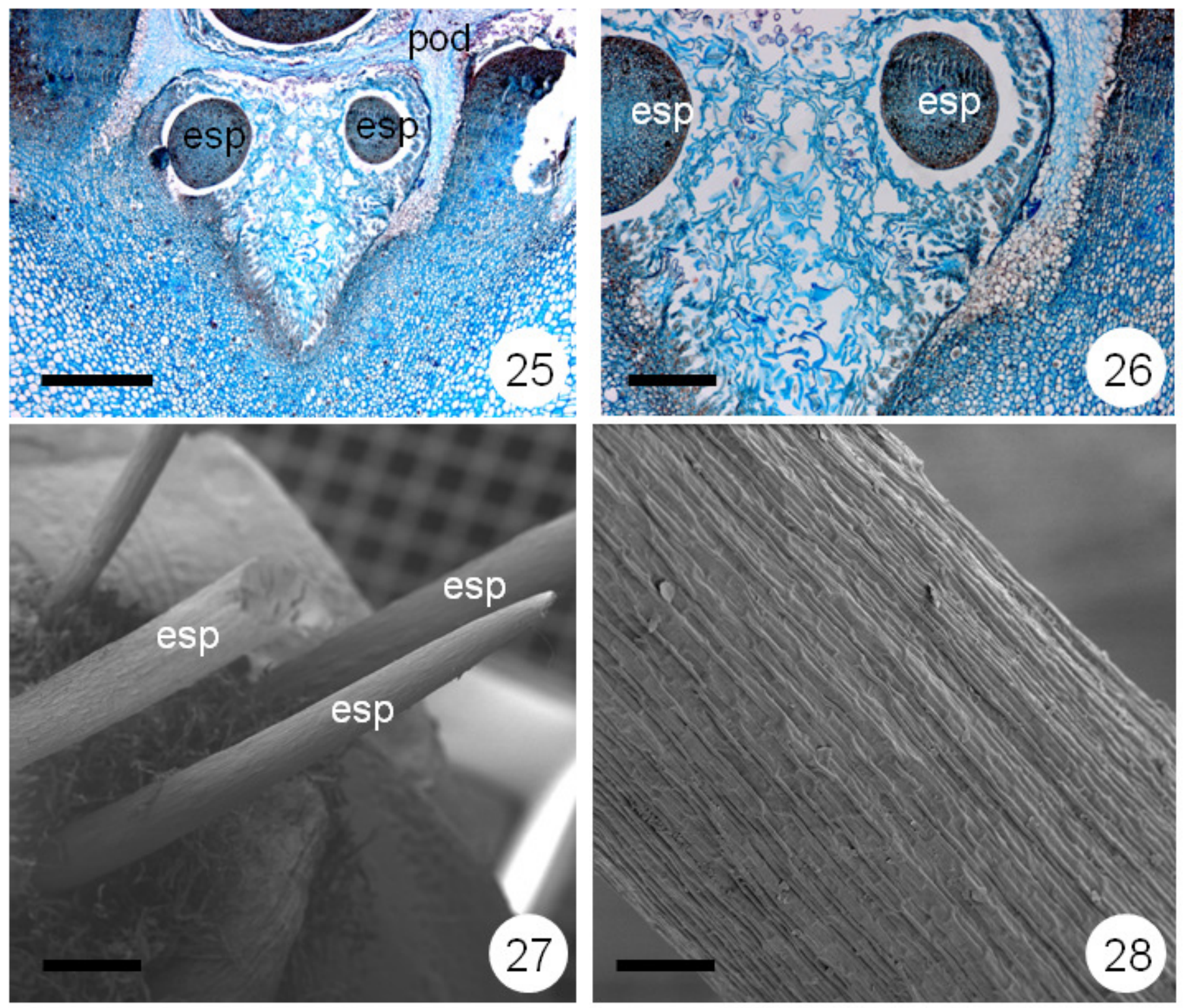

Figuras 25-28: Pereskia bahiensis. Figs. 25-26: Secçôes transversais da regiäo areolar, onde se observa a poliderme intema aos tricomas, e os espinhos sem procâmbio no interior. Figs. 27-28: Microscopia eletrônica de varredura dos espinhos, mostrando as células lisas da epiderme da estrutura. Fig. 28: Detalhe da epiderme do espinho. Barras: $500 \mu m(25$ e 27), $200 \mu m(26)$ e $100 \mu m(28)$. 

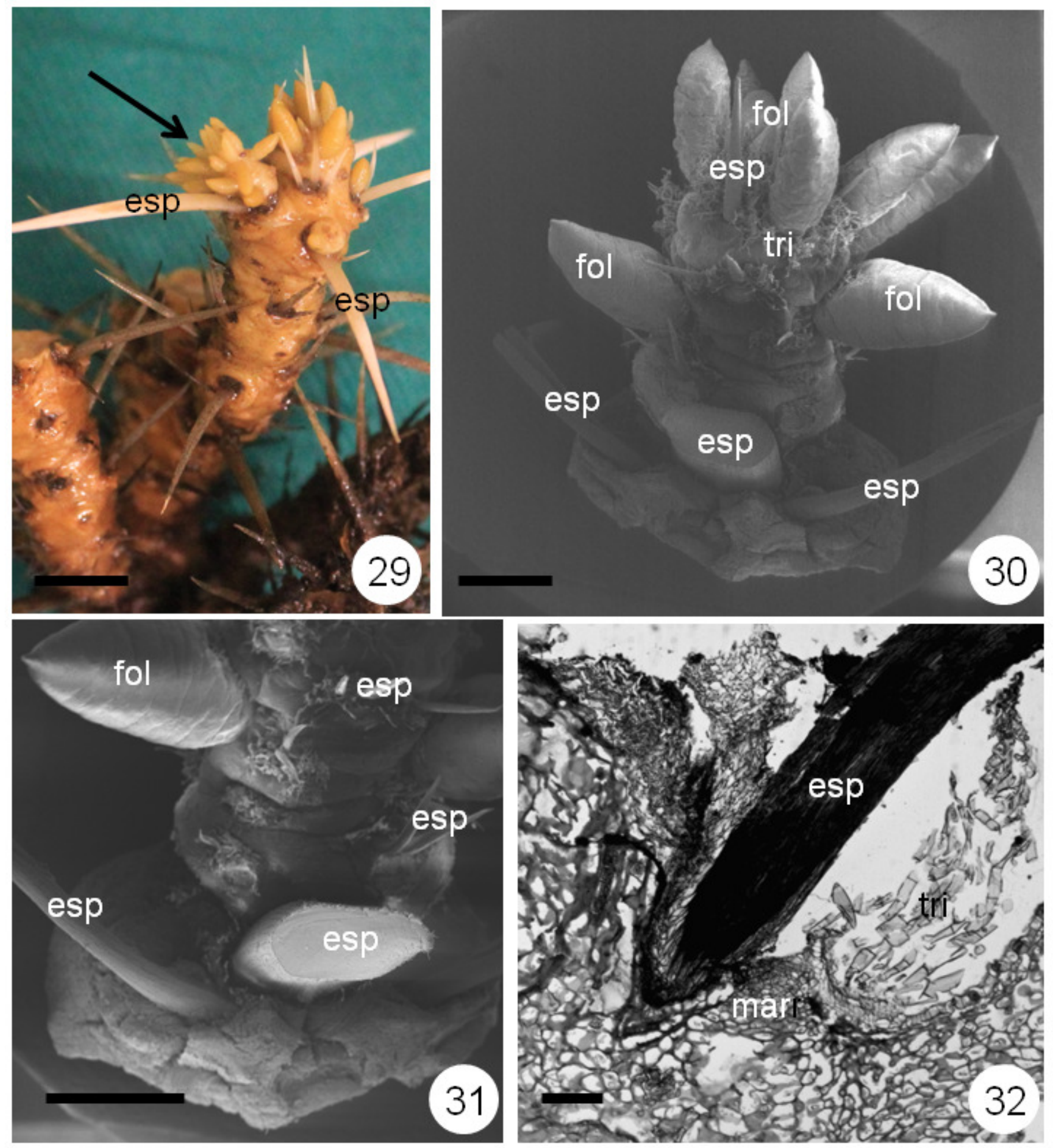

Figuras 29-32: Maihuenia patagonica. Fig. 29: Vista geral do segmento, com segmentos sendo produzidos pelo meristema areolar, com folhas ainda ligadas ao caule. Seta indican do segmento caulinar produzido pelo meristema areolar, tendo o espinhos (esp) na base. Figs. 30-31: Microscopia eletrônica de varredura do segmento caulinar, mostran do folhas (fol), além de várias aréolas com tricomas (tri) e espinhos. Fig. 32: Secçẫo longitudinal da aréola, com espinho na regiẩo abaxial e tricomas na região adaxial do meristema areolar (mar). Barras: $1 \mathrm{~cm}$ (29), $1 \mathrm{~mm}$ (3031) e150 $\mu \mathrm{m}(32)$. 

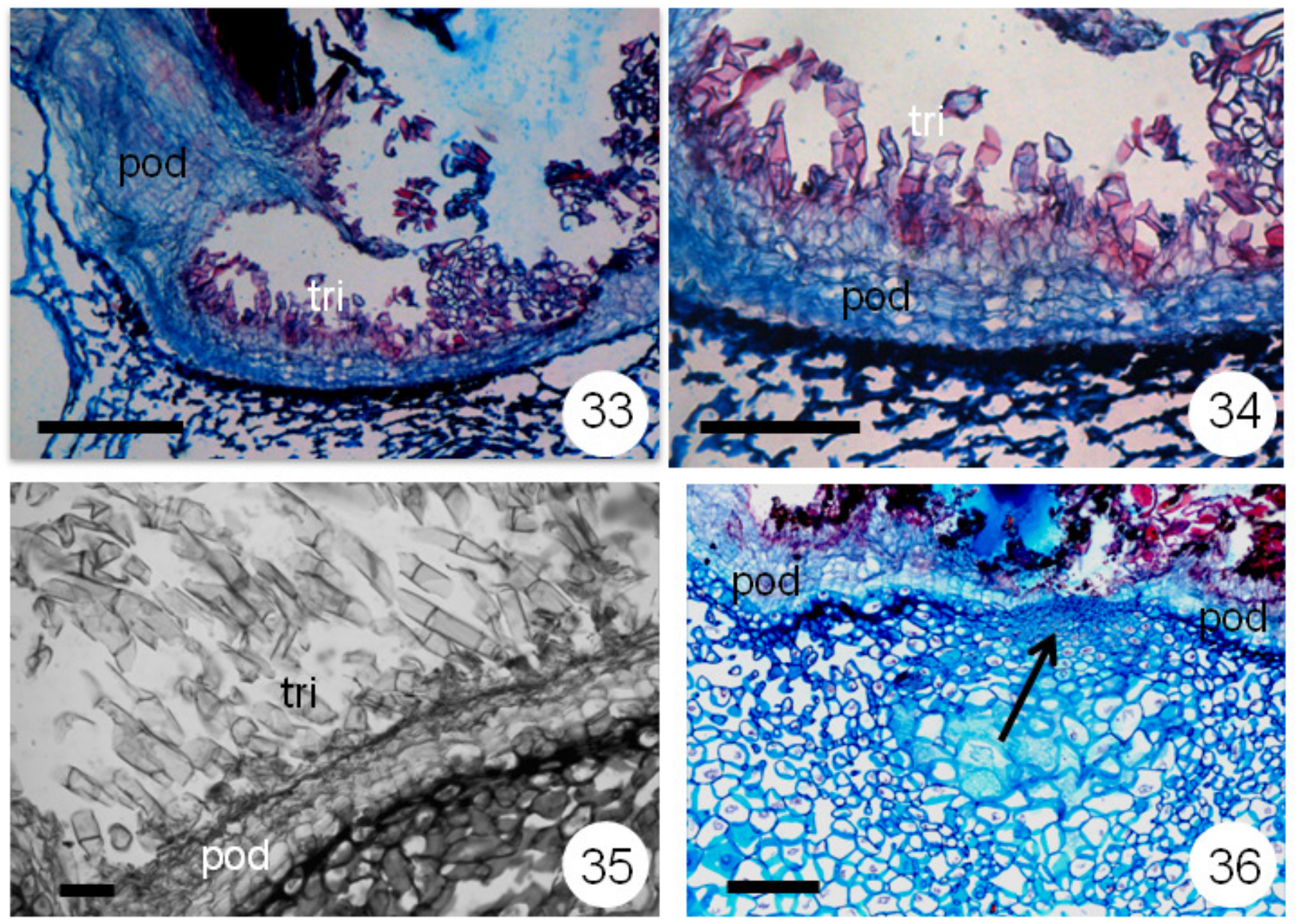

Figuras 33-36: Secçôes Iongitudin ais do segmento caulinar de Maihuenia patagonica, mostran do tricomas (tri) unisseriados e multicelulares e poliderme (pod), presente em toda a regiâo com exceçăo ao meristema areolar (36 - seta). Barras: $490 \mu \mathrm{m}$ (33), 250 $\mu \mathrm{m}(34), 60 \mu \mathrm{m}(35)$ e $200 \mu \mathrm{m}(36)$. 

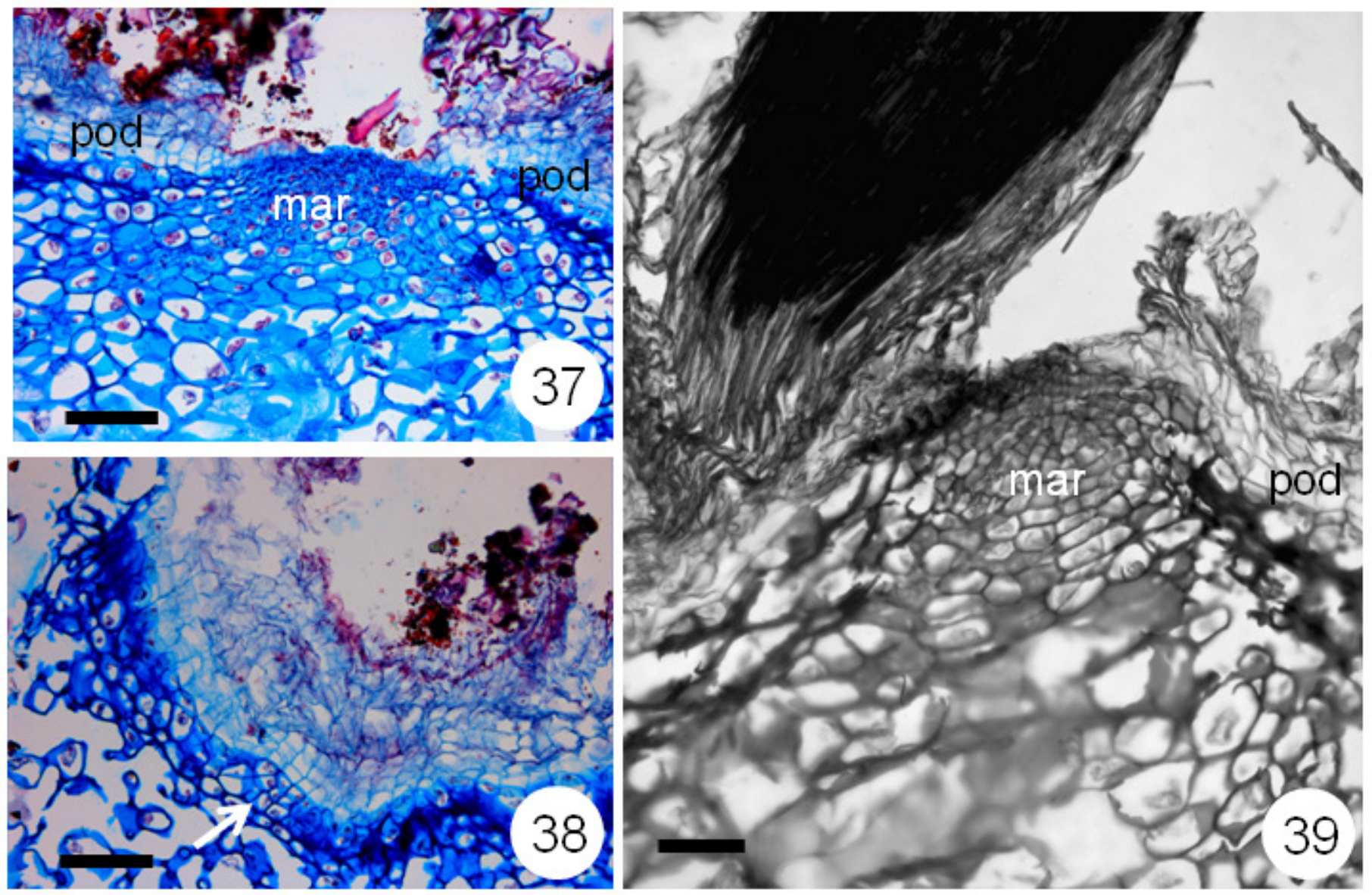

Figuras 37-39: Secçôes longituniais de Maihuenia patagonica. Figs. 37-38: Poliderme (pod) de origem subepidérmica. Fig. 37: Detalhe meristema areolar (mar) com a poliderme se forman do próximo mas nâo sobre ele. Fig. 38: Regiẫo em que se pode observar felogênio produzindo a poliderme (seta). Fig. 39: Espinho próximo ao meristema areolar, com células não esclerificadas na base, e células bastante esclerificadas no restante da estrutura. Notar diferença entre a base do espinho e a poliderme. Barras: $100 \mu m$ (37 e 38) e $50 \mu m(39)$. 

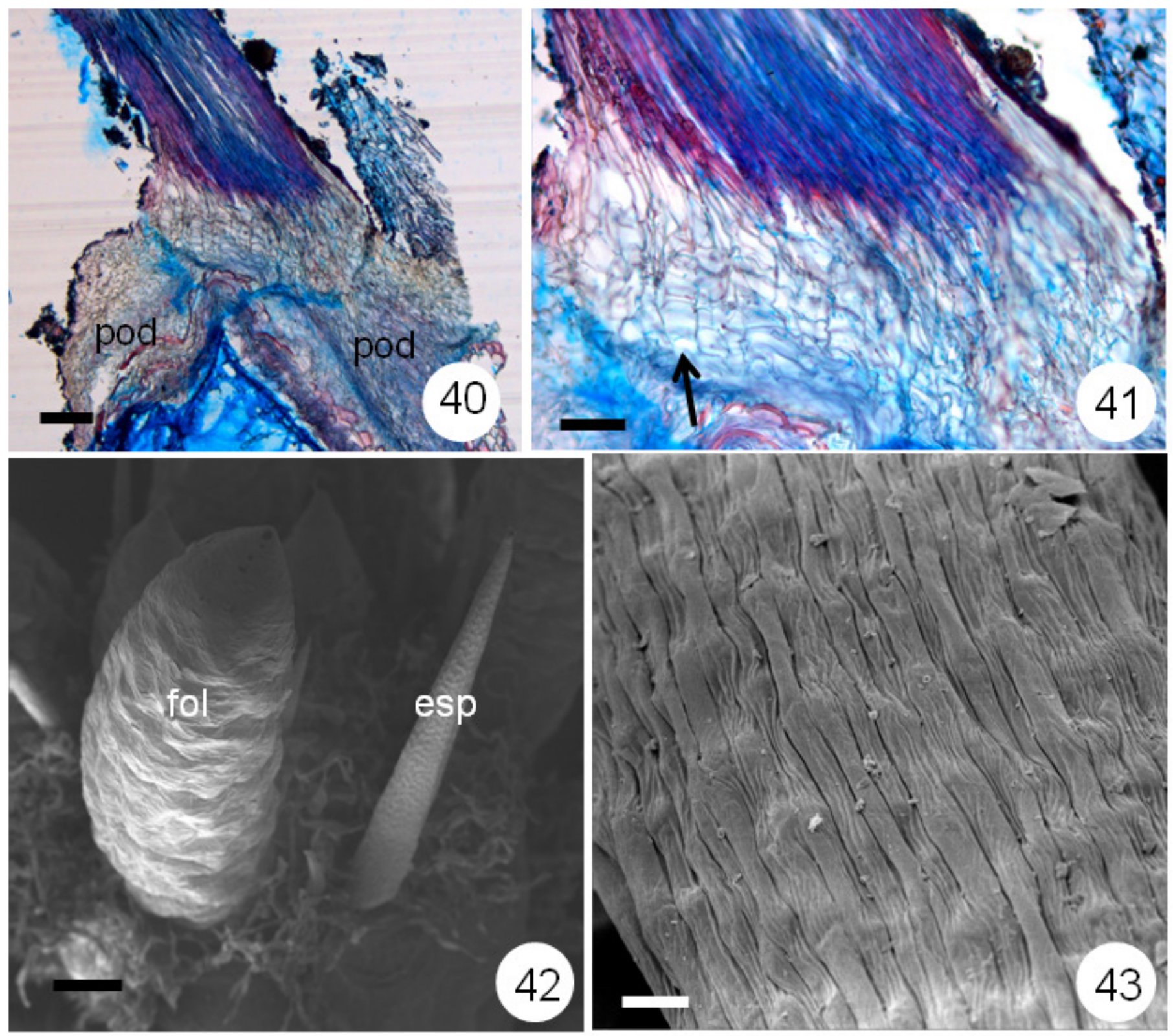

Figuras 40-43: Maihuenia patagonica. Figs. 40-41: Secçôes transversais do segmento caulinar mostrando espinhos com células esclerificadas no ápice e base näo esclerificada, que tem organizaçấo diferente da poliderme (pod). Fig. 41: Detalhe da células da base do espinhos, seta indicando radiaçâo. Figs. 42-43: Microscopia eletrônica de varredura mostran do regiấo areolar com folha (fol) e espinho (esp) com células epidermicas lisas. Fig. 43: Detalhe das células epidermicas do espinho. Barras: $140 \mu \mathrm{m}$ (40), $65 \mu \mathrm{m}$ (41), $200 \mu \mathrm{m}$ (42) e $20 \mu \mathrm{m}$ (43). 

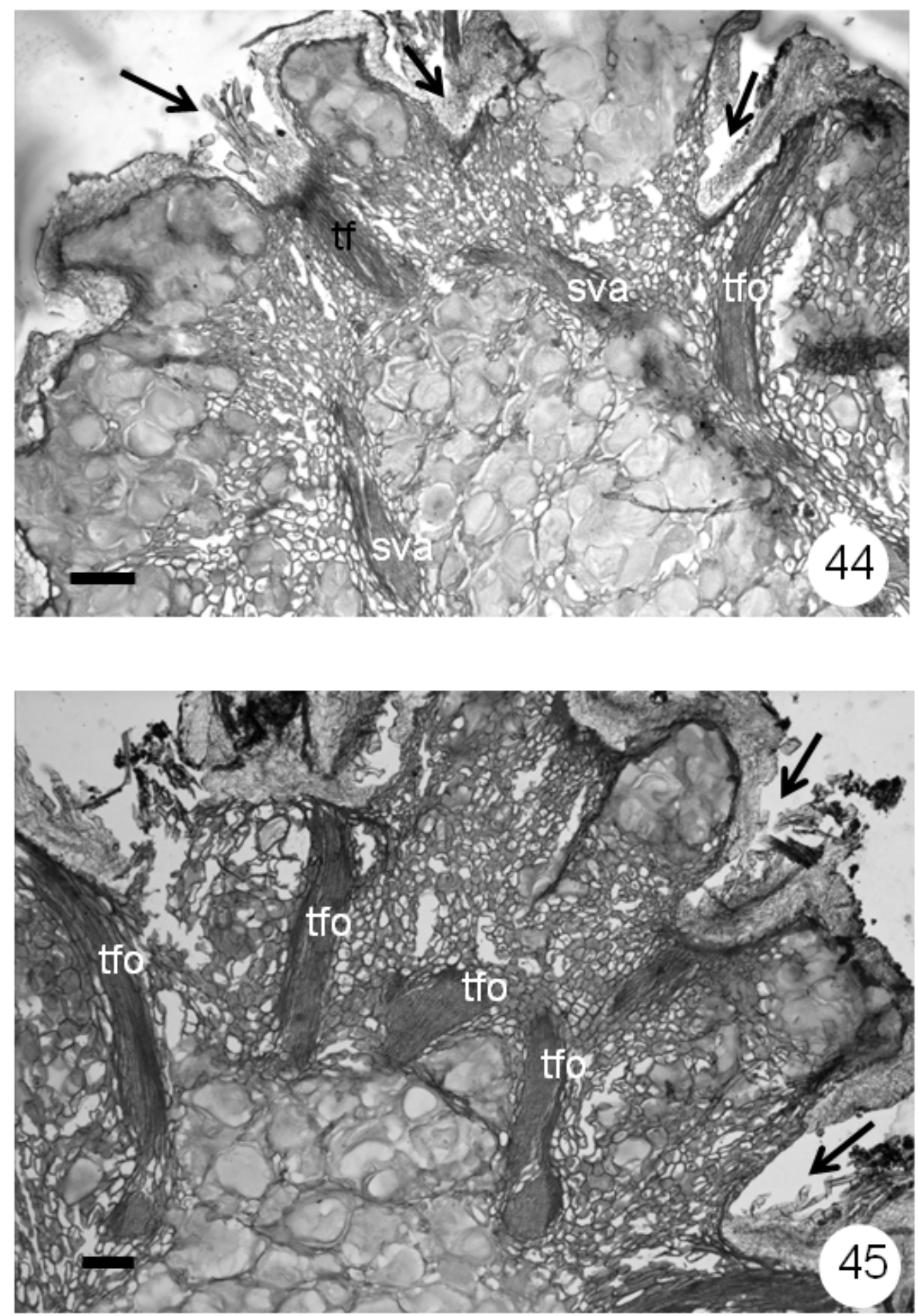

Figuras 44-45: Secçôes longitudin ais do segmento caulinar de Maihuenia patagonica, mostran do a vascularização do sistema caulinar, representado pelo traço foliar (tfo) e feixe caulinar no estelo (sva), setas in dican do regiôes areolares. Barras: $180 \mu \mathrm{m}$ (44) e $140 \mu \mathrm{m}(45)$. 

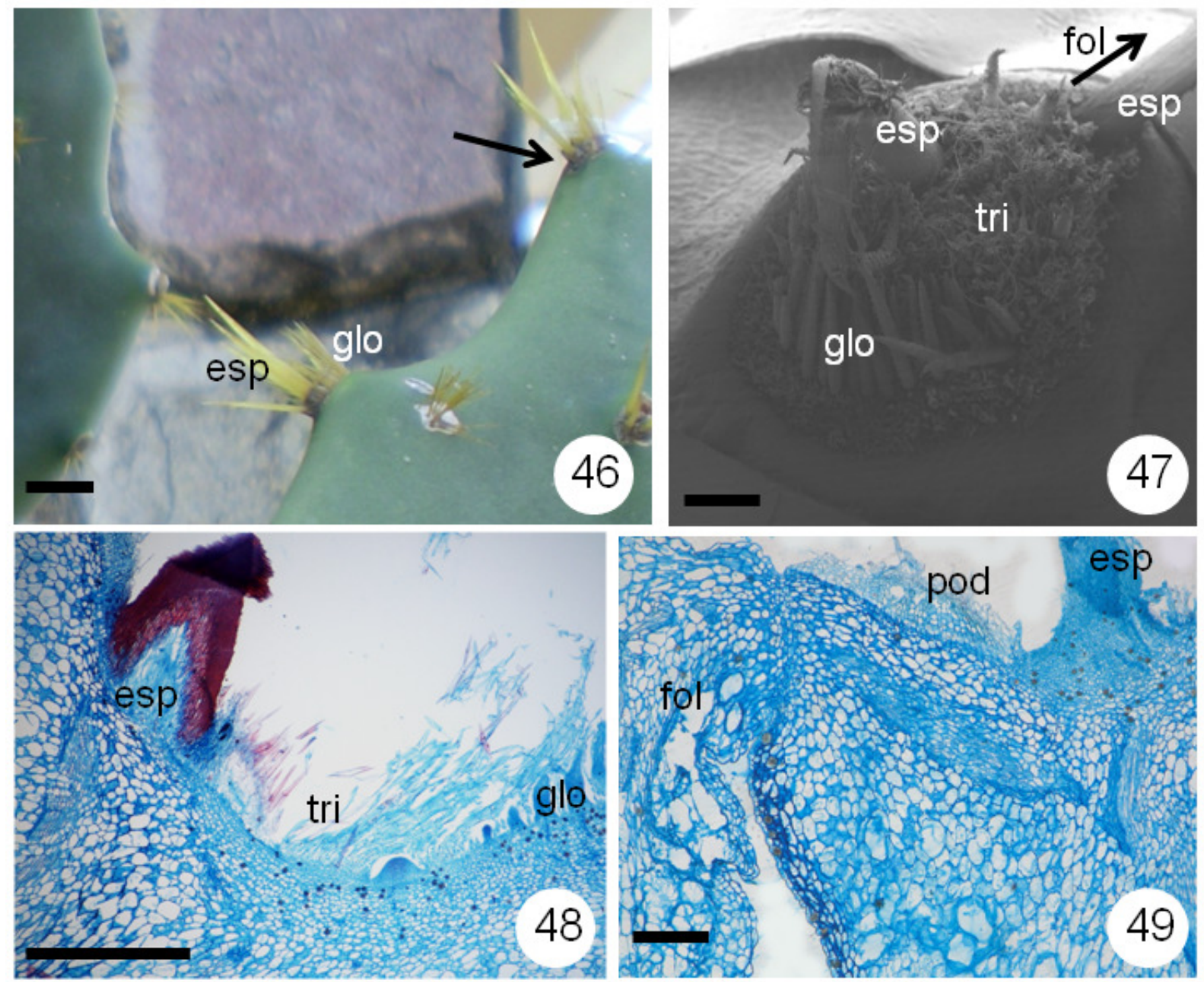

Figuras 46-49: Opuntia dillenii, mostrando simetria bilateral Fig. 46: Vista geral da aréola (seta), com espinho (esp) produzidos abaxialmente e gloquídeos (glo) adaxialmente. Fig. 47: Microscopia eletrônica de varredura de uma aréola, coberta por tricomas (tri), direção de onde a folha (fol), originada do meristema apical (seta). Figs 48-49: Secções longitudinais da aréola, mostrando gloquídeos produzidos na redião adaxial (48), e espinhos na região abaxial da aréola, e a poliderme na periferia (49). Barras: $1 \mathrm{~cm}$ (46), $500 \mu \mathrm{m}$ (47), $680 \mu \mathrm{m}(48)$ e $340 \mu \mathrm{m}$ (49). 


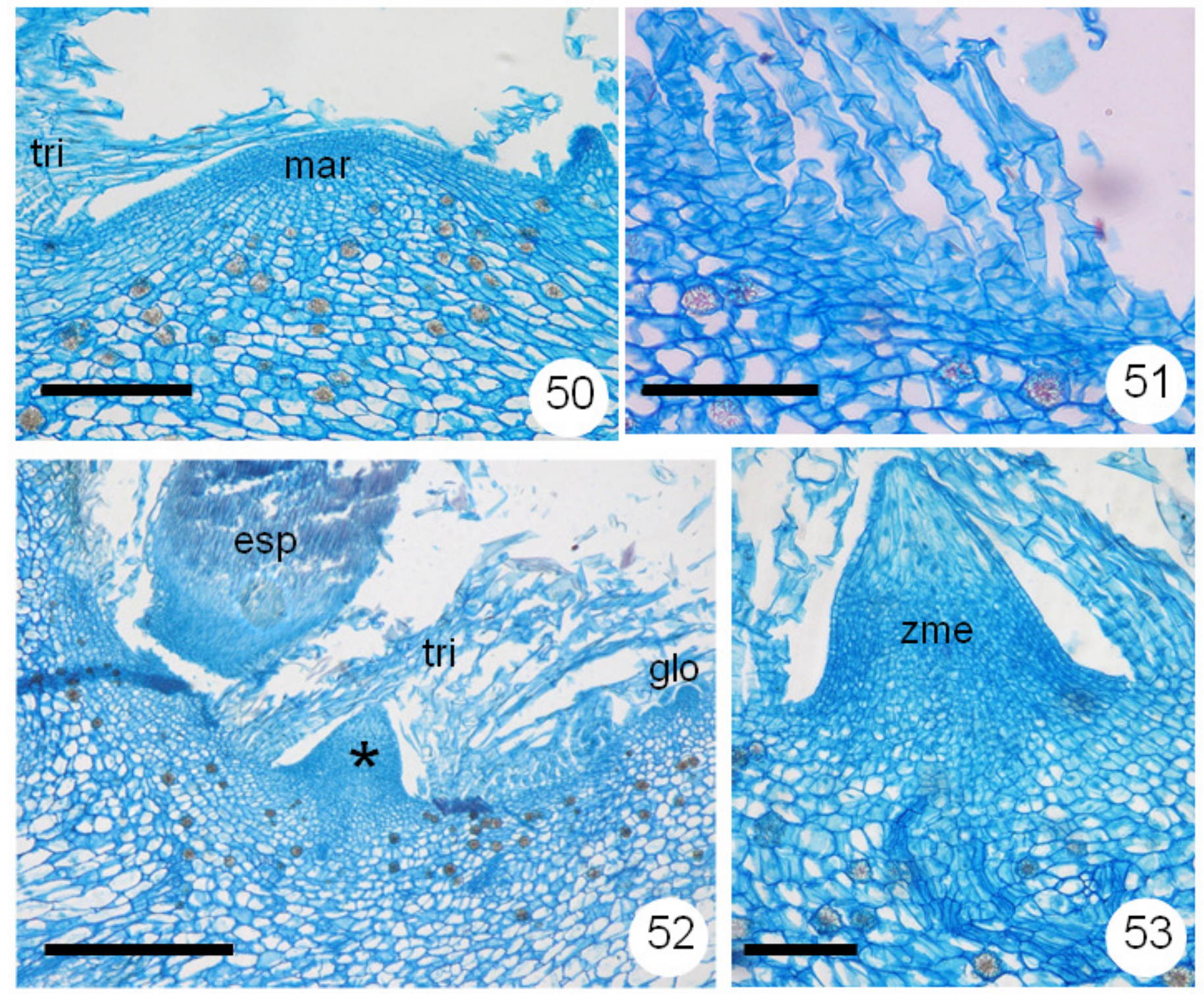

Figuras 50-53: Secçôes lon gitı dinais Opuntia dillenii. Fig. 50: Meristema areolar (mar) e tricomas (tri) produzidos pelas células protodérmicas. Fig. 51: Detalhe dos tricomas unisseriados e multicelulares. Figs. 52: Regiäo areolar com espinhos desenvolvido (esp) e em desenvolvimento ( $\left.{ }^{(}\right)$. Notar primórdios de gloquídeos (glo) no lado oposto aos espinhos. Fig. 53: Detalhe do espinho em desenvolvimento, mostrando a base meristemática (zme) e regiấo apical da estrutura com células alongadas. Barras: 160 $\mu \mathrm{m}(50), 120 \mu \mathrm{m}$ (51), $490 \mu \mathrm{m}$ (52) e $80 \mu \mathrm{m}$ (53). 

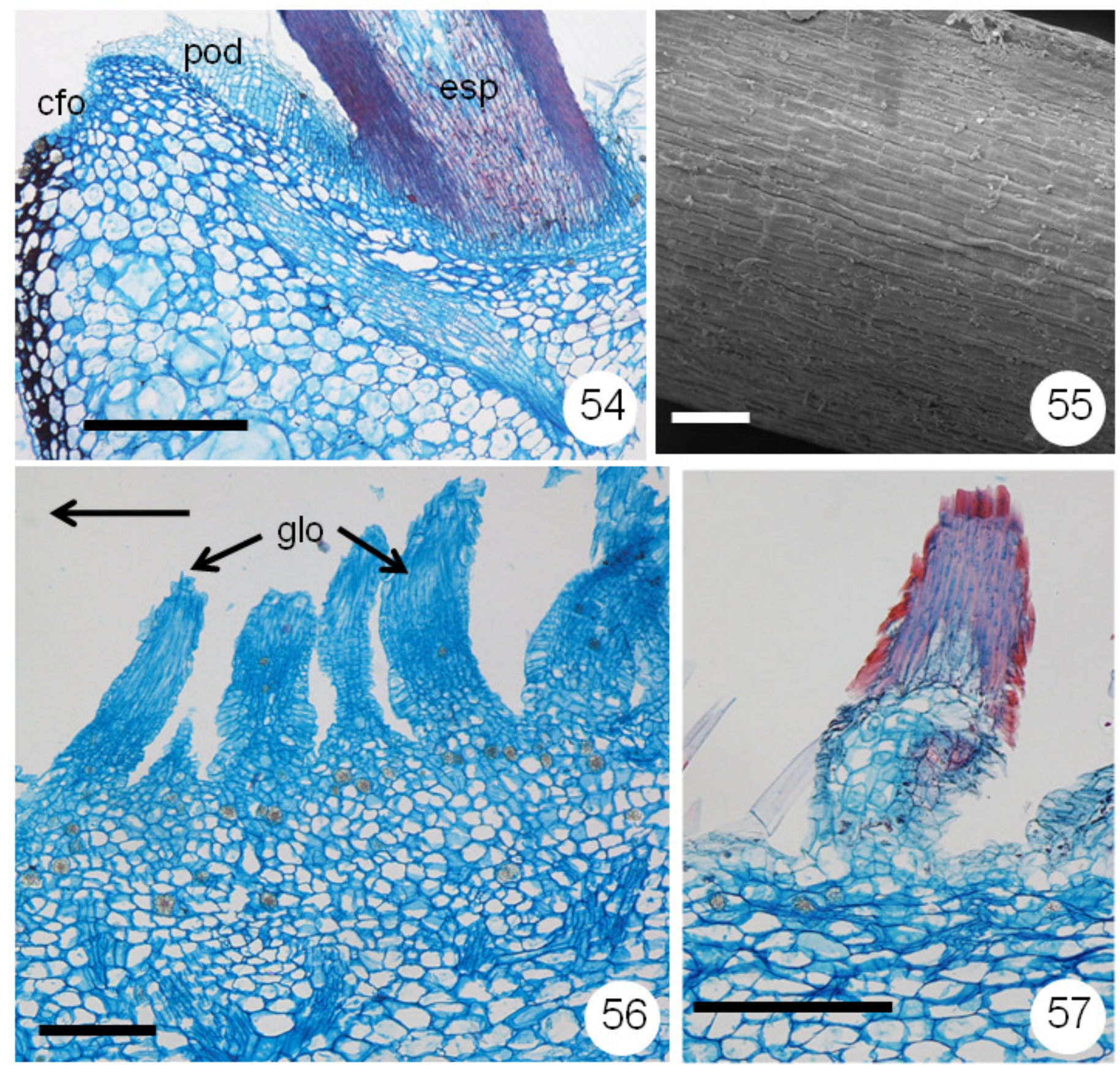

Figuras 54-57: Opuntia dilienii. Fig. 54: Secçẩo longitudinal da regiẩo areolar com espinho (esp) já desenvolvido, e células basais do espinho sem esclerificaçâo, além da poliderme (pod) na regiấo mais externa da aréola, próxima a cicatriz foliar (cfo). Notar células mais extern as bastante esclerificadas, e células internas menos. Fig. 55: Microscopia eletrônica de varredura do espinho mostran do células epidérmicas lisas. Figs 56-57: Secçôes lon gitu din ais de gloquídeos (glo), com a regiấo apical composta por células alongadas, e um gloquídeo já com esclerificaçẫo no ápice (57). A seta na figura 56 representa a posiçâo da folha em relaçâo a imagem. Barras: $680 \mu m(54)$, $100 \mu m(55), 160 \mu m(56)$ e $250 \mu m(57)$. 

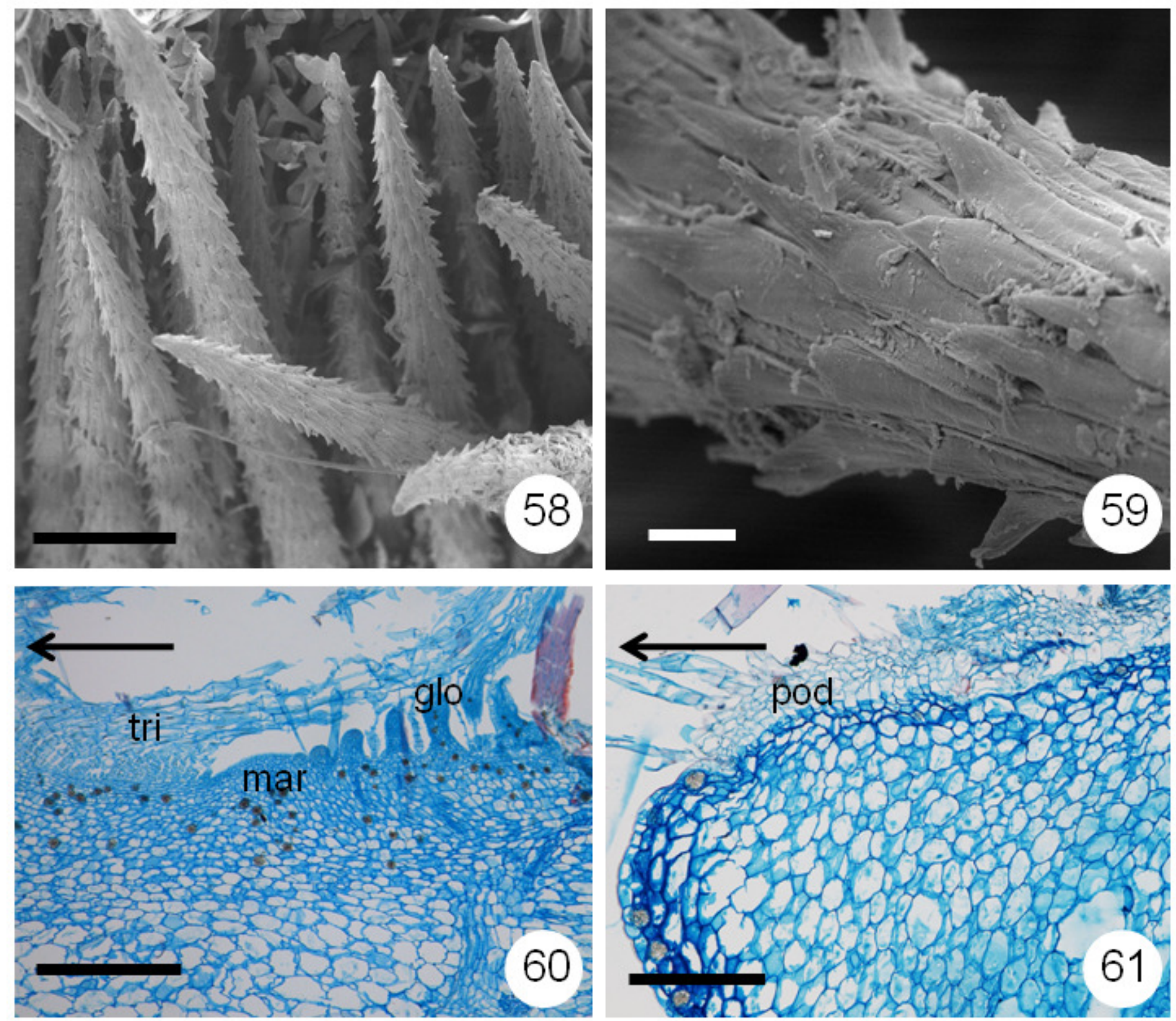

Figuras 58-60: Opuntia dilienii. Figs. 58-59: Microscopia eletrônica de varredura de gloquídeos, mostrando as células epidérmicas em forma de farpas. Fig. 60-61: Secçôes longitudin ais da regiäo areolar. Fig. 60: Meristema areolar (mar) produzindo primórdios de gloquídeos (glo) adaxialmente, tricomas abaxiais Ausência de poliderme. Fig. 61: Poliderme (pd) próxima à folha de origem do meristema apical. As setas nas figuras 60 e 61 indicam a posiçẫo da folha em relaçâo a imagem.Barras: $200 \mu \mathrm{m}$ (58), $20 \mu m(59), 490 \mu m(60)$ e $250 \mu m(61)$. 